\title{
CENTRAL BANK COMMUNICATION \\ AND THE IMPACT OF PUBLIC ANNOUNCEMENTS OF NEW MONETARY POLICY DATA \\ ON THE REACTION OF FOREIGN EXCHANGE AND STOCK MARKETS: EVIDENCE FROM POLAND
}

We analyze the impact of monetary policy communication of the National Bank of Poland (NBP), i.e. the NBP announcements of interest rates changes and the release of new macroeconomic figures, on the Polish financial market in its two main segments: the foreign exchange market and the stock market, and we provide evidence on how they react to public information from the NBP. In particular, we are interested in the uncertainty (i.e. risk) effects and the wealth (i.e. return) effects of the NBP communication, i.e. whether the NBP announcements had any influence on stock and foreign exchange returns and on the activity of those two markets. Using GARCH methodology, we document the negative effects in the conditional variance of GARCH class models of WIG index volume of trade and WIG returns as well as PLN/USD bid-ask spread and PLN/USD returns, which suggests the existence of the calming effects of the NBP communication with financial markets on their price volatility and on the changes of their activity. The evidence presented in our study indicates that the NBP announcements had stabilizing effects on the stock and foreign exchange markets in Poland.

Keywords: macroeconomic announcements; interest rates; National Bank of Poland (NBP); foreign exchange market; stock market; returns volatility; market activity.

JEL Classifications: E5, F3, G1, O2, P3

DOI: $10.15611 /$ aoe.2017.2.02

\section{INTRODUCTION}

The establishment of independent central banks in Central and Eastern European (CEE) countries is a relatively new development and there is, therefore, not much evidence accumulated yet, which indicates whether

\footnotetext{
* Newcastle Business School (NBS), Northumbria University, Newcastle-upon-Tyne, United Kingdom and University of Łódź, Poland.

${ }^{* * *}$ University of Łódź, Poland.

**** Southern Illinois University Edwardsville, Edwardsville, IL, USA. The Centre for European Integration Studies (ZEI), Bonn, Germany. The Emerging Markets Group (EMG), London, United Kingdom. The William Davidson Institute (WDI), Ann Arbor, MI, USA.
} 
central banks announcements in these economies can create wealth effects via movements in stock prices and foreign exchange rates and whether they can reduce market uncertainty. In this study, we analyze the impact of monetary policy communication of the National Bank of Poland (NBP), i.e. the NBP decisions about the changes of interest rates and the NBP announcements of new macroeconomic figures, on the Polish financial market. We provide evidence on how investors react to public information released by the NBP in two main segments of the financial sector: the foreign exchange market and the stock market.

Our study is similar in spirit to the work by Gómez, Melvin and Nardari (2006) who investigated how the actions of the European Central Bank (ECB) affected investor reaction and, hence, the determination of the Euro exchange rate. It is also related to a recent paper by Bastidon, Huchet and Kocoglu (2016) who evaluated the effect of the ECB's monetary policy announcements on interbank spreads in the period between July and December 2011 during the Eurozone sovereign debt crisis. ${ }^{1}$

We focus on Poland for a few reasons. First, it is by far the largest financial market and the biggest economy in the CEE region. For example, according to the Bank for International Settlements (BIS) triennial reports, the BIS snapshot surveys conducted in 2001, 2004, 2007, 2010, 2013 and 2016 show that Poland's foreign exchange market was roughly twice as large in size as the markets in the Czech Republic and in Hungary (see: Triennial Central Bank Survey, 2007, 2010, 2013 and 2016). The Polish stock market is also the biggest in the region. The Warsaw Stock Exchange (WSE) is the largest market of its kind in Central and Eastern Europe and the one that is most dynamically growing among all the European stock trading centres. In terms of the number of the new initial public offerings (IPOs), in 2012 the WSE was the most active market not only in the CEE region but also in the whole of Europe. The issuers listed on the WSE represented about $51 \%$ of companies from the region's exchanges and their share in equities trading in Central and Eastern Europe went up to 54.2\% in 2012 (see: Fact Book 2013. Warsaw Stock Exchange, 2013). Second, there have been significant institutional and macroeconomic changes, including central bank development, after Poland implemented market reforms in the 1990s and

\footnotetext{
${ }^{1}$ Bastidon, Huchet and Kocoglu (2016) found that the ECB's announcements did not have consistently an overall calming effect. For example, although the asset buyout announcements decreased market stress, the liquidity provision releases had a stressing effect while interest rates and liquidity provision announcements did not have any significant effect at all.
} 
subsequently joined the European Union (EU) in 2004. Third, the NBP has been conducting, as a rule, a transparent communication policy with financial markets and since August 2000 it has been regularly publishing a wide range of macroeconomic data regarding its monetary policy variables. The calendar of these announcements is known and disseminated a long time in advance, so market participants always know it and can take it into account in their investment decisions.

In this study, we are interested in the uncertainty (i.e. risk) effects and also in the wealth (i.e. return) effects of the NBP communication. Our findings have significant theoretical and policy implications. First, our results can help understand how monetary transmission mechanism works in emerging economies undergoing significant institutional and macroeconomic changes, such as in Poland. Second, as the evidence on the effects of public information released by central banks (reviewed in the next section) is still limited, our results may contribute to a better understanding of the link between the monetary policy executed by central banks, its implementation in practice and, subsequently, may be useful for the construction of new theoretical models of asset price determination. If a significant empirical link exists between monetary policy announcements and foreign exchange market activity, then exchange rates could play a more important role in monetary policy decisions. Third, our results have implications for short-term investors because we provide daily evidence of whether central bank communication creates significant changes in market returns affecting investors' wealth and market risk through changes in prices and in trading volume.

The remainder of this paper is organized as follows. Section 2 provides a literature review of the impact of public announcements on financial markets with a focus on the newly emerging European markets. Section 3 discusses methodology, section 4 describes the data, while sections 5, 6 and 7 report the empirical results. The last section 8 offers discussion, some policy implications of the main findings and our final conclusions.

\section{LITERATURE REVIEW}

The available empirical literature evidencing the impact of public announcements on financial markets and asset prices in emerging market countries, in particular in the CEE region, is limited and contributes predominantly to our understanding of the reactions of returns of various financial instruments (mainly in the stock market) while very few papers 
concern the trading volume and the dynamics of market activity captured by the volume of trade data. ${ }^{2}$ As an example, to the best of our knowledge there exists only one previous study which used the currency volume of trade data from the foreign exchange market in Poland (Brzeszczyński and Kutan, 2015).

Generally, the existing international literature presents two related streams of papers: one focusing on the impact of global news, represented usually by the announcements made in the United States (US), and one on the domestic news.

Wongswan (2009) provided evidence about the impact of the US monetary policy announcement surprises on equity indexes in developed and emerging economies. The reported results show large and significant response of Asian, European and Latin American equity indexes to the US monetary policy announcement surprises at short time horizons. However, in the Wongswan (2009) study no CEE country was included (it covered only some other emerging market countries in Asia and Latin America).

Nikkinen, Omran, Sahlström and Äijö (2006) analyzed the behaviour of volatilities around 10 important scheduled US macroeconomic announcements on stock markets in several world regions, including such countries as the Czech Republic, Poland, Hungary, Slovakia and Russia. Using cross-sectional monthly data, they find that these markets as a group are not affected by the US announcements.

Hanousek, Kočenda and Kutan (2009) analyzed the impact of foreign macroeconomic announcements (from the US and the EU) on stock market returns using the intra-day data from the Czech Republic, Hungary and Poland. They reported that all these markets are subject to significant spillovers directly via the composite index returns from neighbouring markets or indirectly through the transmission of macroeconomic news.

Korczak and Bohl (2005) investigated, among others, the changes in home market stock prices and trading volume around depositary receipts issuance on a sample of the Czech, Hungarian, Polish, Russian, Slovak and Slovenian stocks and report significant increases in both the stock prices and volume.

Another paper on the emerging markets, but analyzing different types of announcements, is the work by Kaminsky and Schmukler (2002). They investigated what types of local and neighbouring-country news caused

\footnotetext{
${ }^{2}$ For a recent review of the literature on the link between public announcements and financial markets reactions in emerging economies see: Brzeszczyński, Gajdka and Kutan (2015).
} 
stock market movements during the Asian crisis. The results show that the news about agreements with international organizations and credit rating changes turned out to be most important in explaining large movements in stock prices.

Ganapolsky and Schmuckler (2001) analyzed the reaction of Argentina's stock market index, Brady bond prices and Peso-deposit interest rates to policy announcements and news reports received by markets during the Mexican crisis of 1994-1995. Those types of information that were perceived as increasing the credibility of the currency board (i.e. the agreement with the International Monetary Fund, the dollarization of reserve deposits in the central bank and changes in reserve requirements) had a positive impact on market returns. In a related paper, Robitaille and Roush (2006) provided evidence about the impact of the US macro data and the FOMC announcements on the stock market index in Brazil and on the yield spread in the Brazilian government US Dollar-denominated bonds market.

These existing studies for emerging markets, especially the ones using the data from the CEE countries, have focused mainly on stock markets and there is only a small number of papers, which concern other market segments. For example, Poghosyan, Kočenda and Zemčik (2008) found that the Armenian central bank's foreign exchange market interventions affected public expectations regarding foreign exchange fluctuations. Similarly, Loiseau-Aslanidi (2011) reported that sterilized foreign exchange interventions by the National Bank of Georgia increased the volatility (i.e. conditional variance) of the domestic currency exchange rate against the US Dollar. Andritzky, Bannister and Tamirisa (2007) presented an investigation of the emerging market bonds reaction to macroeconomic announcements and demonstrated that all analyzed news affected the volatility of the bonds market. However, the announcements appeared to matter less for countries with more transparent policies and higher credit ratings. Frömmel, Han and Gysegem (2015) examined the link between jumps in the Hungarian Forint/Euro exchange rate and news releases. They found that scheduled and unscheduled news announcements explain about half of the significant jumps in the foreign exchange market in Hungary.

Serwa (2006) provided evidence on the short-term reactions of the emerging financial market in Poland to the domestic central bank monetary policy announcements measured by the movements in the official interest rate. The findings reported by Serwa (2006) show that only the short-term interest rates respond significantly to the official interest changes but not the long-term interest rates, stock indices and foreign exchange rates. Moreover, 
the unexpected monetary policy changes have a stronger influence on the money market than the nominal changes in the official interest rate on the days of the monetary policy announcements. Our paper is different from that work. While Serwa (2006) focuses on the official rate changes, we analyze a broader group of announcements made by the Polish central bank, including those on interest rates and a number of monetary aggregates.

In another paper related to ours, Rozkrut et al. (2007) investigated the impact of statements of the key policy makers related to future monetary policy decisions (verbal statements reported by major news agencies and official communiqués of the central banks) on the exchange rates in three CEE countries. They found that the verbal comments of policy makers in the Czech Republic, Hungary and Poland influence the behaviour of the currency market, however this effect varied within the analysed group. Our paper also differs from Rozkrut et al. (2007). They examined verbal statements, while we focus on the NBP communications.

Brzeszczyński and Kutan (2015) analysed the reaction of the currency market in Poland to the NBP communication of the new monetary policy data, but the investigated period covered only the early years from 2000 to 2003 and a smaller selection of the NBP announcements. The evidence presented by Brzeszczyński and Kutan (2015) suggests that the NBP's actions stabilized the markets in terms of reduced volatility and that they also increased investors' activity.

Among other studies which focused on the Polish data, Ziarko-Siwek (2004) investigated the market rates' reaction to the NBP reference rate changes in Poland and found that, although the Polish financial market was generally not efficient, some interest rates (e.g. long-term bond market rates) were responding consistently with the expectations implied by the efficient market hypothesis.

Kubacki (2014) analysed how markets in Poland, the Czech Republic and the UK reacted to the central banks announcements about the decision to change (or not to change) the level of the reference rate. This study focused on the instruments representing the short-term section of the yield curve, long-term section of the yield curve and the stock market. Kubacki (2014) argued that although it is difficult to draw firm conclusions about the efficiency of the markets under consideration, as they are not fully informationally efficient, the UK market was found to have a higher level of transparency and credibility than the markets in the Czech Republic and Poland. 
Janecki (2012) examined the reaction of the interbank market and bonds market to the decisions about the NBP reference rate changes in the period 2001-2011. The results of this study show that the unexpected rate changes caused more significant interbank rates reaction and that the reference rate increase had a stronger impact than its decrease on the interbank market. Janecki (2012) also found that the short-term interbank market rates were characterized by stronger reactions to the decisions about the reference rates than the long-term interbank market rates. However, the differences between the interbank and bonds markets were so large that it was not possible to formulate any uniform conclusion about the reaction of both markets to the central bank decisions.

Włodarczyk (2008) investigated the impact of the Monetary Policy Council (MPC) members' comments on the prices of FRA contracts, interest rates SWAPs and on the expectations of market participants in Poland in the period from February 2004 to March 2007 and found that the MPC, through their members' comments, may have had an influence on market expectations and the prices of some financial assets (e.g. FRA contracts).

Saba and Kudła (2014) examined how the changes of the NBP reference rate impact the prices and the volatility of the WIG20 index, i.e. the index of the largest and the most liquid stocks of the Polish capital market. They split the changes of interest rates taking place after the decisions of the MPC and extract the expected and unexpected components. Subsequently, using the GARCH-type models, they assessed the direction and strength of the impact of these components on the changes of the WIG20 index and its volatility. This analysis confirmed the impact of the unexpected interest rate changes but not the expected ones. However, at the same time there was no evidence that stronger unexpected changes or changes headed in particular direction (positive or negative) had a significant impact on the value of the stocks on the Warsaw Stock Exchange.

Filipowicz (2013) investigated how stock returns react to the changes of the NBP reference rate using the data for 9 stocks from the WIG20 index and based on the ARMA-GARCH type models. The results of this study show that only in some cases the stock prices reacted to the NBP interest rate decisions.

Będowska-Sójka (2016) examined the behaviour of liquidity measures (trading volume, number of transactions, volatility and market depth) around the time of price jumps on the Warsaw Stock Exchange employing intradaily data. Using the 10-minutes returns for the most liquid stocks quoted on the Polish stock market, this study reported that macroeconomic and firm 
specific news are not associated with significant jumps in the liquidity variables, which suggests the limited role of public information releases and the larger role of private information during the investigated sample period.

Baranowski and Gajewski (2016) provided evidence on the forward guidance (FG) policy credibility in Poland by investigating changes in the professional forecasters' perceived ex-ante monetary policy rule associated with the introduction of the FG policy. Using the Taylor rule framework and employing micro-level data, they tested the perception of monetary policy in Poland among professional forecasters. The results presented in the study by Baranowski and Gajewski (2016) show that the Taylor principle was violated in the forward guidance period, which is interpreted as the evidence in favour of the credibility of the forward guidance approach.

Büttner and Hayo (2012) analysed the impact of news on the financial markets (interbank deposits, bond, currency and stock markets) in the Czech Republic, Hungary and Poland using the GARCH models' framework. They found that macroeconomic shocks significantly affected short-term interest rates and, to a lesser extent, other financial variables. Political and fiscal news had an impact on long-term bond yields and on the exchange rates. News displayed prominently in the media had a greater impact on financial markets than other news. In addition, the sources of news themselves also appear to matter. Büttner and Hayo (2012) further discovered the asymmetric effects of news on the investigated markets. Finally, they also found that macroeconomic shocks had the strongest impact on financial markets in Hungary, while political news had the strongest influence both in Hungary and in Poland.

Kapuściński et al. (2014) presented a comprehensive analysis of the monetary policy transmission mechanism in Poland. They found that it is broadly similar to the mechanisms functioning in the developed markets. The most visible changes observed in Poland lately, according to their findings, include the decreasing role of the foreign exchange rates on the consumption prices and stronger reaction of inflation to the central bank interest rates movements.

Overall, in the available literature there exist only limited studies on the emerging markets, especially those in the EU countries. Moreover, most of them focus on financial market returns and they do not examine the effects related to trading volume. Our paper, however, presents new results for the foreign exchange market and stock market using not only the price returns but also the variables which capture the foreign exchange and stock market trading activity. 
The literature also provides suggestions as to why investors in emerging financial markets, and their reactions to news, may be different than those in other countries. For example, Serwa (2006) argues that emerging markets may react with low sensitivity to the monetary policy events due to the weakness of their monetary authorities, the limited confidence of investors in their actions and the inefficiency of their financial markets. Wongswan (2009) provides empirical evidence showing that the size of equity markets' reactions in response to the US monetary policy news in the sample of 15 emerging and developed markets varies greatly across those countries and that the cross-country response variation is linked to the proxies of their level of financial integration with the US as the world's leading market. Hausman and Wongswan (2011) analyzed the impact of the US monetary policy surprises on equity indexes, interest rates and foreign exchange rates in 49 countries and also found significant variations across them, which was related to the differences in exchange rate regimes and the proportion of asset holdings owned by the US investors in those markets. Hence, it is reasonable to argue that the responses of the emerging and developed markets depend on the level of their development, strength of monetary policy authorities and integration of their markets with the global financial system.

In summary, the available results for the emerging markets, especially those in the new EU countries, are still scarce. Our study extends, therefore, the existing literature by providing new evidence for both the foreign exchange and stock market using not only the stock market and foreign exchange rate returns but also the variables capturing the investors' activity in both those market segments.

\section{METHODOLOGY}

In this study, we focus on the stock market and on the foreign exchange market and we construct models for stock market index returns, stock market activity as well as foreign exchange rate returns and foreign exchange market activity.

We exploit the following dependent variables in the respective models. For the stock market we use broad stock market index WIG index returns and WIG index volume of trade, while for the foreign exchange market we use PLN/USD exchange rate returns and PLN/USD bid-ask spread. In these models we introduce dummy variables to capture the NBP announcements effects. Models of WIG index returns and PLN/USD exchange rate returns 
allow us to investigate the effects in prices (i.e. wealth effects) while models of WIG index volume of trade and PLN/USD bid-ask spread help us understand the impact on investors' activity which affects the volatility of prices (i.e. risk effects). In the absence of the availability of the volume of trade data for the foreign exchange market, we use the bid-ask spread as a proxy of market activity (assuming that trading volume and bid-ask spread are inversely related). ${ }^{3}$

Because strong ARCH effects were detected in all models (models of returns, trading volume and bid-ask spread), we utilize GARCH methodology (c.f. Engle, 1982 and Bollerslev, 1986) as our modelling approach. Due to their specific design, the GARCH models are a very convenient methodological framework to investigate the effects of announcements in both: (a) mean equation (capturing wealth effects) and (b) conditional variance equation (where variance is a proxy for risk).

Below we present a detailed description of the methodology applied in this paper. ${ }^{4}$

\subsection{Modelling effects in stock market index returns and volatility}

We propose to estimate the following $\operatorname{GARCH}(1,1)$ model to capture the effects of the NBP communication in the WIG index returns $\left(r_{t}^{W I G}\right)$. It includes the NBP announcement dummies for each variable in the conditional variance equation:

$$
\begin{gathered}
r_{t}^{W I G}=\alpha_{0}+\xi_{t} \\
h_{t}=\beta_{0}+\beta_{1} \xi_{t-1}^{2}+\beta_{2} h_{t-1}+\beta_{3} D U M_{t}
\end{gathered}
$$

where:

$$
D U M_{t}=I N T R A T E, M S, R M, B P M, B P Q, A L, \ldots \text { etc. }
$$

\footnotetext{
${ }^{3}$ The volume of trade databases from the foreign exchange market are not publicly available and for this reason there exist very few papers which use such data in academic research (see, for example, the study by Brzeszczyński and Melvin (2006) which relies on the data obtained directly from Reuters currency dealing platform as a proprietary source). Given such limited access to the foreign exchange market volume data, the bid-ask spread is the best possible proxy variable that can be employed to capture the changes in the currency market activity.

${ }^{4}$ The methodology adopted in this study follows the approach and the modelling techniques proposed by Brzeszczyński and Kutan (2015).
} 
Its extended version is as follows:

$$
\begin{gathered}
r_{t}^{W I G}=\alpha_{0}+\alpha_{1} \text { rvolume }_{t-1}+\xi_{t} \\
h_{t}=\beta_{0}+\beta_{1} \xi_{t-1}^{2}+\beta_{2} h_{t-1}+\beta_{3} \text { rvolume }_{t-1}+\beta_{4} D U M_{t}
\end{gathered}
$$

where rvolume $_{t}$ is the percentage change of the WIG volume (turnover by value).

The NBP announcements of the interest rate and the new macroeconomic figures describing the changes in the NBP monetary policy, which we employed in this study, are: (1) Interest Rate (INTRATE), (2) Money Supply $(M S)$, (3) Reserve Money $(R M)$, (4) Balance of Payments - monthly (BPM), (5) Balance of Payments - quarterly (BPQ), (6) Official Reserves (OFRES), (7) Liquid Assets and Liabilities in Foreign Currencies $(A L)$, (8) Foreign Debt (FDEBT) and (9) International Investment Position (IIP).

The lagged volume variable rvolume $_{t-1}$ is introduced in the mean equation (3) under the assumption that price and quantity in the stock market are determined jointly (so we do not assume independent random walks). In the conditional variance equation (4) the lagged rvolume $_{t-1}$ is used to avoid any possible simultaneity bias, which could appear if it was omitted from the model. We adopted a similar approach in the subsequent models discussed in this section and in the next sections of the paper.

We also test whether the central bank announcements affect the mean of the stock market returns by including the dummy variables in the mean equation and we propose to estimate the following GARCH model:

$$
\begin{gathered}
r_{t}^{W I G}=\alpha_{0}+\alpha_{1} D U M_{t}+\xi_{t} \\
h_{t}=\beta_{0}+\beta_{1} \xi_{t-1}^{2}+\beta_{2} h_{t-1}
\end{gathered}
$$

and its extended version:

$$
\begin{gathered}
r_{t}^{\text {WIG }}=\alpha_{0}+\alpha_{1} \text { rvolume }_{t-1}+\alpha_{2} \text { DUM }_{t}+\xi_{t} \\
h_{t}=\beta_{0}+\beta_{1} \xi_{t-1}^{2}+\beta_{2} h_{t-1}+\beta_{3} \text { rvolume }_{t-1} .
\end{gathered}
$$

The estimation method applied in all ARCH class models in our study was based on the Marquardt algorithm (Marquardt, 1963) available as a standard option in EViews software. We performed all the estimations assuming that the residuals are conditionally normally distributed. However, we further checked the variants of the models with other distributional 
assumptions, which we discuss later in the section dealing with the robustness analyses.

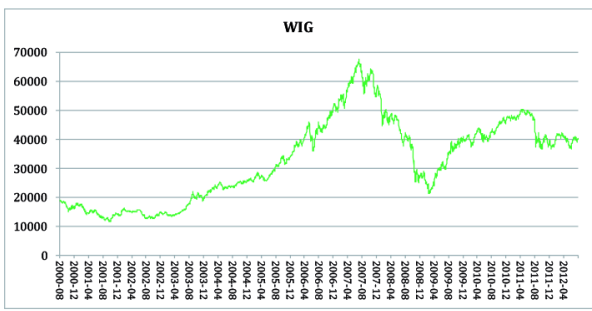

Figure 1a. WIG index

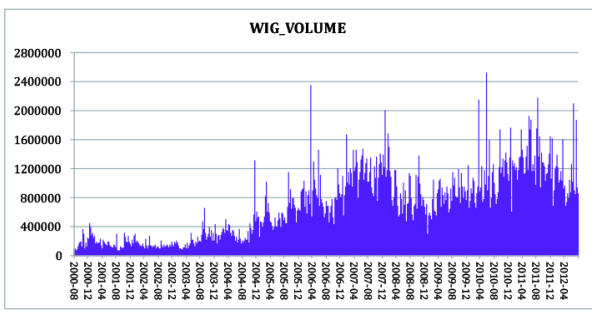

Figure 2a. WIG index volume of trade

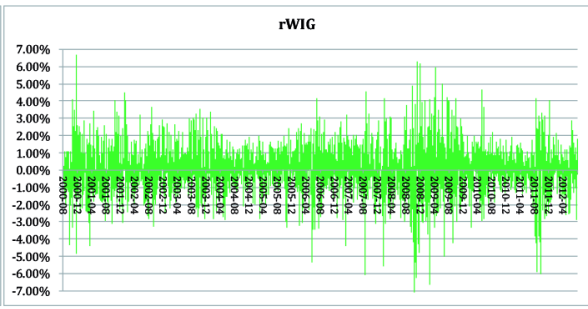

Figure 1b. WIG index returns

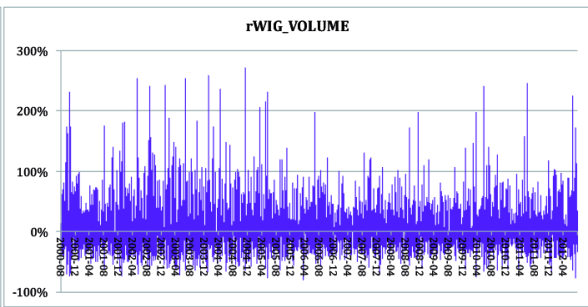

Figure $2 b$.WIG index volume of trade percentage changes

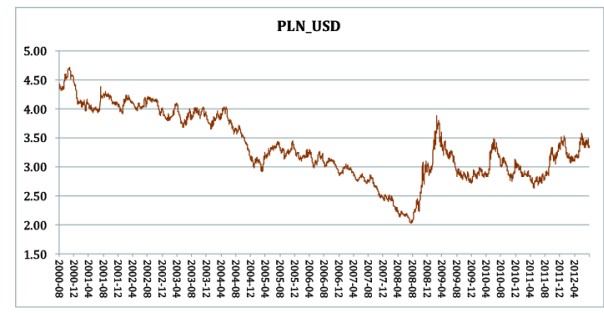

Figure 3a. PLN/USD exchange rate

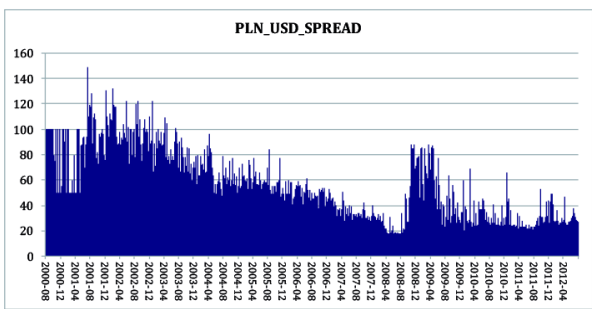

Figure 4a. PLN/USD exchange rate bid-ask spread

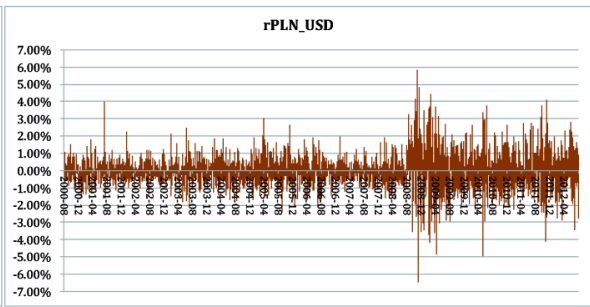

Figure $3 b$. PLN/USD exchange rate returns

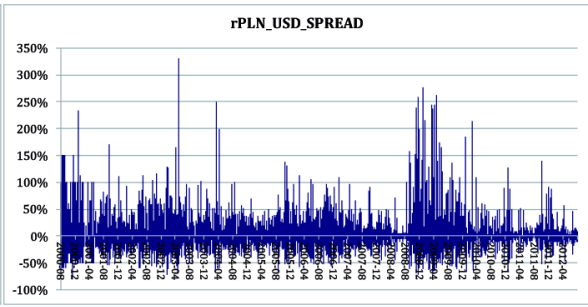

Figure $4 b$. PLN/USD exchange rate bid-ask spread percentage changes.

Source: Warsaw Stock Exchange (WSE), Datastream and Bloomberg. 
Following Cheung and $\mathrm{Ng}$ (1996), who argue that the failure to include the dummy variables, which are significant in the variance equation of an ARCH class model, in the mean equation may affect the estimation results, we adopted the approach that in all our models the parameters for the dummy variables are estimated jointly (i.e. in one estimation for the mean equation and for the conditional variance equation).

In all the models in our study (discussed in this section and in all the other subsequent sections) we rigorously tested for the existence of autocorrelation. If autocorrelation was detected, we removed it by imposing an appropriate structure of AR and/or MA terms. We used the Ljung-Box Q test and we confirmed at the $\mathrm{Q}(10)$ level that all the results in all the models are free from autocorrelation.

Figures $1 \mathrm{a}-1 \mathrm{~b}$ present the WIG index (levels and returns) over the entire sample period from 1 August 2000 to 31 July 2012.

The proposed methodology allows to address directly the main goal of our paper by measuring both the uncertainty and wealth effects of the NBP communication. Uncertainty effects are quantified by the dummy variables that capture the influence of the NBP announcements on the level of the conditional variance in the ARCH class models, which is interpreted as the impact on the increase or on the decrease of market risk (depending on the sign of the estimated dummy parameters). Similarly, the wealth effects are quantified by the dummy variables introduced in the mean equation of the ARCH class models, which measure the impact of the NBP announcements on the subsequent movements of the analyzed prices (which we model as their returns). Statistically significant effects in the mean equation suggest that investors may be able to exploit the movements of prices following the NBP communication events and construct investment strategies leading to profitable financial outcomes (hence, the wealth effects may be possible to achieve in practice as a result of such investment decisions relying on information about the NBP news).

\subsection{Modelling effects in stock market activity and volatility}

Similarly, we employ a GARCH model to assess the impact of the NBP communication on the changes in activity of stock market investors captured by the WIG index volume of trade $\left(\right.$ rvolume $_{t}$ ) with the NBP announcement dummy variables in the conditional variance equation:

$$
\begin{gathered}
\text { rvolume }_{t}=\alpha_{0}+\alpha_{1} r_{t-1}^{W I G}+\xi_{t} \\
h_{t}=\beta_{0}+\beta_{1} \xi_{t-1}^{2}+\beta_{2} h_{t-1}+\beta_{3} D U M_{t} .
\end{gathered}
$$


In order to test whether the announcements have any impact on the mean of the WIG volume variable, we also employ the following GARCH model where the NBP announcements dummies are now included in the mean equation:

$$
\begin{gathered}
\text { rvolume }_{t}=\alpha_{0}+\alpha_{1} r_{t-1}^{W I G}+\alpha_{2} D U M_{t}+\xi_{t} \\
h_{t}=\beta_{0}+\beta_{1} \xi_{t-1}^{2}+\beta_{2} h_{t-1}
\end{gathered}
$$

Figures $2 \mathrm{a}-2 \mathrm{~b}$ present the WIG index volume of trade (levels and percentage changes) over the entire sample period from August 2000 to July 2012.

\subsection{Modelling effects in foreign exchange returns and volatility}

In order to evaluate the effects of the NBP communication in the foreign exchange market, we propose to estimate the following $\operatorname{GARCH}(1,1)$ model of the PLN/USD exchange rate returns $\left(r_{t}^{\text {PLN/USD }}\right.$ ) with the announcement dummies for each variable introduced in the conditional variance equation:

$$
\begin{gathered}
r_{t}^{P L N / U S D}=\alpha_{0}+\xi_{t} \\
h_{t}=\beta_{0}+\beta_{1} \xi_{t-1}^{2}+\beta_{2} h_{t-1}+\beta_{3} D U M_{t}
\end{gathered}
$$

where:

$$
D U M_{t}=I N T R A T E, M S, R M, B P M, B P Q, A L, \ldots \text { etc. }
$$

and its extended version:

$$
\begin{gathered}
r_{t}^{\text {PLN /USD }}=\alpha_{0}+\alpha_{1} \text { rspread }_{t-1}+\xi_{t} \\
h_{t}=\beta_{0}+\beta_{1} \xi_{t-1}^{2}+\beta_{2} h_{t-1}+\beta_{3} \text { rspread }_{t-1}+\beta_{4} \text { DUM }_{t}
\end{gathered}
$$

where sspread $_{t}$ is the percentage change of the PLN/USD bid-ask spread.

We also test whether the unexpected central bank announcements affect the mean of the foreign exchange rate returns by including the dummy variables in the mean equation, so we propose to estimate the following GARCH model: 


$$
\begin{gathered}
r_{t}^{P L N / U S D}=\alpha_{0}+\alpha_{1} D U M_{t}+\xi_{t} \\
h_{t}=\beta_{0}+\beta_{1} \xi_{t-1}^{2}+\beta_{2} h_{t-1}
\end{gathered}
$$

and its extended version:

$$
\begin{gathered}
r_{t}^{P L N / U S D}=\alpha_{0}+\alpha_{1} \text { rspread }_{t-1}+\alpha_{2} \text { DUM }_{t}+\xi_{t} \\
h_{t}=\beta_{0}+\beta_{1} \xi_{t-1}^{2}+\beta_{2} h_{t-1}+\beta_{3} \text { rspread }_{t-1} .
\end{gathered}
$$

Figures $3 a-3 b$ present the PLN/USD exchange rate (levels and returns) over the entire sample period from August 2000 to July 2012.

\subsection{Modelling effects in foreign exchange market activity and volatility}

Similarly, we employ a GARCH model to estimate the impact of the NBP announcements on the changes in activity of currency market investors captured by the PLN/USD bid-ask spread $\left(\right.$ rspread $\left._{t}\right)$ with the announcement dummy variables in the conditional variance equation:

$$
\begin{gathered}
\text { rspread }_{t}=\alpha_{0}+\alpha_{1} r_{t-1}^{P L N / U S D}+\xi_{t} \\
h_{t}=\beta_{0}+\beta_{1} \xi_{t-1}^{2}+\beta_{2} h_{t-1}+\beta_{3} D U M_{t} .
\end{gathered}
$$

The impact of the announcements on the mean of the bid-ask spread variable is captured by the following GARCH model where the NBP communication dummies are now included in the mean equation:

$$
\begin{gathered}
\text { rspread }_{t}=\alpha_{0}+\alpha_{1} r_{t-1}^{P L N / U S D}+\alpha_{2} D U M_{t}+\xi_{t} \\
h_{t}=\beta_{0}+\beta_{1} \xi_{t-1}^{2}+\beta_{2} h_{t-1} .
\end{gathered}
$$

Figures $4 \mathrm{a}-4 \mathrm{~b}$ present the PLN/USD exchange rate bid-ask spread (levels and percentage changes) over the entire sample period from August 2000 to July 2012.

\section{DATA AND SAMPLE PERIOD}

Our sample covers 12 years from 1 August 2000 until 31 July 2012. The beginning of this period was chosen as 1 August 2000 because August in the year 2000 was the first month when regular announcements by the Polish 
central bank NBP started. The frequency of data in our database is daily and it covers a total of 3131 observations.

We capture the NBP announcements by constructing dummy variables for the interest rate change announcements and for the new macroeconomic figures releases on the announcement day (day $t$ ) and for the following day (day $t+1)$. Across all the NBP announcements in the entire period of our analysis in the 12 years sample from 1 August 2000 to 31 July 2012 we have a total of 862 events.

The two main sources of data, which we used for the construction of our database, are as follows: (1) National Bank of Poland (data about the NBP announcement dates of new macroeconomic figures and interest rates) and (2) Datastream and Bloomberg (data about stock market and foreign exchange market prices, volume of trade and bid-ask spreads).

Table 1

The NBP interest rate and macroeconomic data announcements in the period from 1 August 2000 to 31 July 2012

\begin{tabular}{|c|c|c|c|}
\hline Announcements & $\begin{array}{c}\text { Number } \\
\text { of announcements }\end{array}$ & Frequency & $\begin{array}{c}\text { Timing } \\
\text { of announcements }\end{array}$ \\
\hline $\begin{array}{l}\text { Interest rate } \\
(\text { INTRATE })\end{array}$ & 50 & Irregularly & $\begin{array}{c}\text { Announcement after the } \\
\text { decision of the Monetary } \\
\text { Policy Council }\end{array}$ \\
\hline $\begin{array}{c}\text { Money Supply } \\
(M S)\end{array}$ & 144 & Monthly & 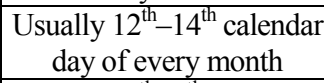 \\
\hline $\begin{array}{c}\text { Reserve Money } \\
(R M)\end{array}$ & 144 & Monthly & $\begin{array}{l}\text { Usually } 5^{\text {th }}-7^{\text {th }} \text { calendar } \\
\text { day of every month }\end{array}$ \\
\hline $\begin{array}{c}\text { Balance of Payments } \\
(B P M)\end{array}$ & 143 & Monthly & $\begin{array}{c}\begin{array}{c}\text { Usually middle of every } \\
\text { month }\end{array} \\
\end{array}$ \\
\hline $\begin{array}{c}\text { Balance of Payments } \\
(B P Q)\end{array}$ & 35 & Quarterly & $\begin{array}{c}\text { Usually end of every } \\
\text { quarter }\end{array}$ \\
\hline $\begin{array}{c}\text { Official Reserves } \\
(\text { OFRES })\end{array}$ & 144 & Monthly & $\begin{array}{c}\text { Usually } 5^{\text {th }}-7^{\text {th }} \text { calendar } \\
\text { day of every month }\end{array}$ \\
\hline $\begin{array}{c}\text { Liquid Assets and Liabilities } \\
\text { in Foreign Currencies } \\
(A L)\end{array}$ & 142 & Monthly & $\begin{array}{l}\text { Usually } 19^{\text {th }}-21^{\text {th }} \\
\text { calendar day of every } \\
\text { month }\end{array}$ \\
\hline $\begin{array}{c}\text { Foreign Debt } \\
(\text { FDEBT })\end{array}$ & 39 & Quarterly & $\begin{array}{c}\text { Usually end of every } \\
\text { quarter }\end{array}$ \\
\hline $\begin{array}{c}\text { International } \\
\text { Investment Position } \\
(I I P)\end{array}$ & 21 & Quarterly & $\begin{array}{c}\text { Usually end of every } \\
\text { quarter }\end{array}$ \\
\hline TOTAL & 862 & & \\
\hline
\end{tabular}

Source: National Bank of Poland and authors' own calculations. 

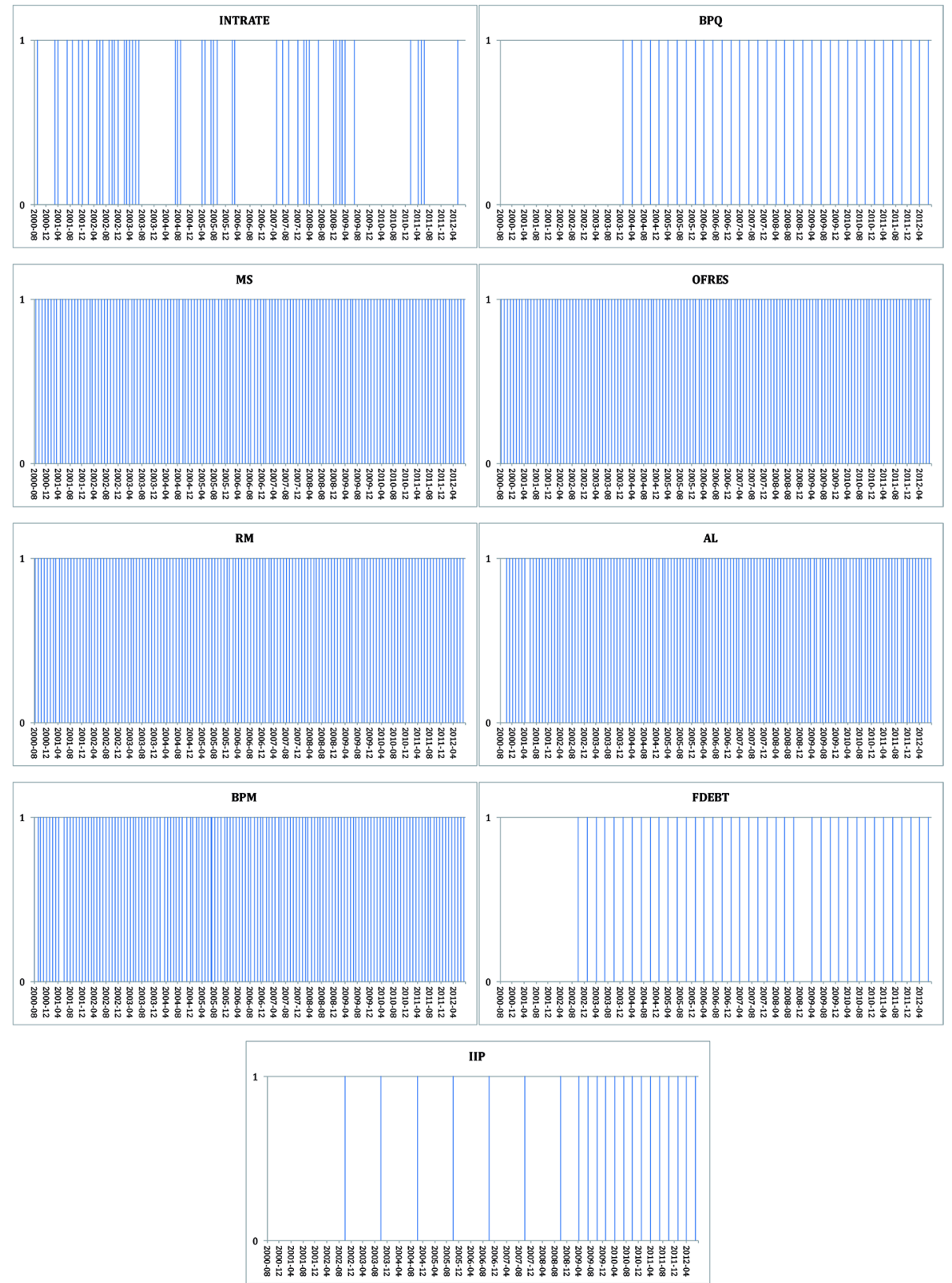

Figure 5. Distribution of the NBP announcements in the period from 1 August 2000 to 31 July 2012

Source: National Bank of Poland. 
The WIG index is quoted on the Warsaw Stock Exchange (WSE) and the WSE is also the original source of the WIG volume of trade data. The foreign exchange rate PLN/USD is quoted on the international interbank currency market and this data (including the bid and ask rates) is reported in Bloomberg.

Table 1 presents a summary of the numbers of individual announcements of interest rate changes and the publication of the new macroeconomic data made by the National Bank of Poland in the period from 1 August 2000 to 31 July 2012, which includes the indication of the frequency of these events (quarterly, monthly or irregularly) and the usual timing of the release of the respective data within the calendar month.

Figure 5 depicts all the NBP announcements, i.e.: Interest Rate (INTRATE), Money Supply (MS), Reserve Money (RM), Balance of Payments - monthly $(B P M)$, Balance of Payments - quarterly $(B P Q)$, Official Reserves (OFRES), Liquid Assets and Liabilities in Foreign Currencies $(A L)$, Foreign Debt $(F D E B T)$ and International Investment Position (IIP), and their distribution over time in the investigated period.

In the next two sections, we investigate the models with the dummy variables constructed for the announcement days for all the variables described in Table 1 and we present our empirical results.

\section{EMPIRICAL RESULTS: STOCK MARKET}

We discuss first the results for the models of stock market index returns and volatility and then for the models of stock market activity and volatility with dummy variables constructed for the NBP announcement days. Subsequently, we analyze the empirical findings for the corresponding types of models for the foreign exchange market with the same NBP dummies.

For all the models we analyze the estimation results in every pair of equations (i.e. mean equation and conditional variance equation) by discussing first the effects in variance and then in the mean.

\subsection{Stock market returns}

Below we present findings for the models of stock market returns and in the next step we turn our attention to the models of stock market activity measured by the changes of the WIG index trading volume.

Table $2 \mathrm{a}$ in the first two top panels reports the estimates of dummy variables for the NBP announcement days with announcement dummies in the conditional variance equation (4) from the GARCH model (3)-(4) of the 
WIG index returns. On the day when the announcements of monetary policy data were made (i.e. on day $t$ ) in 6 out of 9 cases the estimates were statistically significant (for INTRATE, $M S, B P M, A L, F D E B T$ and $I I P$ ) and in all the instances they were negative. On the following day after the NBP communication (i.e. on day $t+1$ ) these effects were weaker and the estimated parameters were significant for only 2 dummy variables, i.e. for $M S$ and $F D E B T$, but - again - both had negative values. This finding means that there exists evidence that the NBP announcements of new monetary policy data had a statistically significant calming impact on the WIG index returns variance and that it was stronger on the announcement day $t$ than on the following day $t+1$.

Table 2a in the bottom two panels presents the estimates of dummy variables for the NBP announcement days with announcement dummies in the mean equation (7) from the GARCH model (7)-(8) for the WIG index returns. On the day of the NBP communication, statistically significant effects were detected in 3 cases for the INTRATE, MS and IIP dummies and all 3 parameters had negative values, however the estimates are significant at only $10 \%$ level. On the following day, there were 2 cases when the NBP announcement dummies were significant (also at the $10 \%$ level). The results in Table 2a indicate possible reversal effects in stock market returns in response to the money supply $(M S)$ announcements with estimates changing sign between days $t$ and $t+1$. A similar pattern of a sign switch of parameters is present in the case of all other dummies INTRATE, RM, BPM, BPQ, OFRES, $A L$ and $F D E B T$ (except only for IIP), however this effect is weaker and less reliable from the statistical point of view because many of those estimates were not significant (although some were close to the $10 \%$ borderline, e.g. the estimate for FDEBT on day $t$ has a significance level of $\mathrm{p}=0.1125){ }^{5}$

\subsection{Stock market activity}

In this subsection, we discuss the models of stock market activity measured by the WIG index trading volume.

The first two top panels in Table $2 \mathrm{~b}$ present the estimates of dummy variables for the NBP announcement days with announcement dummies in

\footnotetext{
${ }^{5}$ Note that the effects of the NBP communication which we capture on the following day $t+1$, after the actual announcement has been made on day $t$, are denoted in the tables with our empirical results accordingly as the effects measured for day $t+1$. However, the models are formulated for time $t$. Therefore, the announcement dummies defined as leads for time $t+1$ represent a shift forward by one period (i.e. by one day) and quantify the effects in both returns and in the conditional variance as intended on day $t+1$.
} 
Table 2a.

Estimates of dummy variables for the NBP announcement days with announcement dummies in the conditional variance equation (4):

$$
h_{t}=\beta_{0}+\beta_{1} \xi_{t-1}^{2}+\beta_{2} h_{t-1}+\beta_{3} \text { rvolume }_{t-1}+\beta_{4} D U M_{t}
$$

from the GARCH model (3)-(4) of the WIG index returns and in the mean equation (7):

$$
r_{t}^{\text {WIG }}=\alpha_{0}+\alpha_{1} \text { rvolume }_{t-1}+\alpha_{2} \text { DUM }_{t}+\xi_{t}
$$

\begin{tabular}{|c|c|c|c|c|c|c|c|c|c|}
\hline Equation: & INTRATE & $M S$ & $R M$ & $B P M$ & $B P Q$ & OFRES & $A L$ & FDEBT & $I I P$ \\
\hline & \multicolumn{9}{|c|}{ On day $t$} \\
\hline \multirow[t]{2}{*}{ (4) } & $\begin{array}{c}-2.07 \times 10^{-5} * * \\
\left(9.10 \times 10^{-6}\right)\end{array}$ & $\begin{array}{c}-2.25 \times 10^{-5} * * * \\
\left(7.54 \times 10^{-6}\right)\end{array}$ & $\begin{array}{c}1.04 \times 10^{-5} \\
\left(9.65 \times 10^{-6}\right)\end{array}$ & $\begin{array}{c}-1.58 \times 10^{-5} * * \\
\left(6.18 \times 10^{-6}\right)\end{array}$ & $\begin{array}{c}1.48 \times 10^{-5} \\
\left(1.26 \times 10^{-5}\right)\end{array}$ & $\begin{array}{c}1.18 \times 10^{-5} \\
\left(9.74 \times 10^{-6}\right)\end{array}$ & $\begin{array}{c}-2.11 \times 10^{-5} * * \\
\left(8.30 \times 10^{-6}\right)\end{array}$ & $\begin{array}{c}-4.29 \times 10^{-5} * * * \\
\left(1.06 \times 10^{-5}\right)\end{array}$ & $\begin{array}{c}-4.48 \times 10^{-5} * * * \\
\left(1.62 \times 10^{-5}\right)\end{array}$ \\
\hline & \multicolumn{9}{|c|}{ On day $t+1$} \\
\hline \multirow[t]{2}{*}{ (4) } & $\begin{array}{c}-1.09 \times 10^{-5} * * \\
\left(9.75 \times 10^{-6}\right)\end{array}$ & $\begin{array}{c}-1.65 \times 10^{-5} * * \\
\left(8.30 \times 10^{-6}\right)\end{array}$ & $\begin{array}{c}1.50 \times 10^{-5} \\
\left(1.10 \times 10^{-5}\right)\end{array}$ & $\begin{array}{c}-2.10 \times 10^{-5} * * * \\
\left(7.05 \times 10^{-6}\right)\end{array}$ & $\begin{array}{c}6.78 \times 10^{-6} \\
\left(1.28 \times 10^{-5}\right)\end{array}$ & $\begin{array}{r}1.54 \times 10^{-5} \\
\left(1.10 \times 10^{-5}\right)\end{array}$ & $\begin{array}{c}-3.74 \times 10^{-5} * * * \\
\left(1.02 \times 10^{-5}\right)\end{array}$ & $\begin{array}{c}-3.50 \times 10^{-5} * * \\
\left(1.38 \times 10^{-6}\right)\end{array}$ & $\begin{array}{l}4.10 \times 10^{-5} * * * \\
\left(1.57 \times 10^{-5}\right)\end{array}$ \\
\hline & \multicolumn{9}{|c|}{ On day $t$} \\
\hline \multirow[t]{2}{*}{ (7) } & $\begin{array}{c}-0.002968 * \\
(0.001555)\end{array}$ & $\begin{array}{c}-0.001707 * \\
(0.000875)\end{array}$ & $\begin{array}{l}-0.000523 \\
(0.000955)\end{array}$ & $\begin{array}{c}0.000467 \\
(0.000889)\end{array}$ & $\begin{array}{c}-0.000293 \\
(0.001589)\end{array}$ & $\begin{array}{l}-0.000542 \\
(0.000970)\end{array}$ & $\begin{array}{c}0.000869 \\
(0.000828)\end{array}$ & $\begin{array}{c}-0.002309 * \\
(0.001290)\end{array}$ & $\begin{array}{c}-0.003342 * \\
(0.001820)\end{array}$ \\
\hline & \multicolumn{9}{|c|}{ On day $t+1$} \\
\hline (7) & $\begin{array}{c}0.000841 \\
(0.001512)\end{array}$ & $\begin{array}{l}0.001589 * \\
(0.000897)\end{array}$ & $\begin{array}{c}0.000565 \\
(0.000969)\end{array}$ & $\begin{array}{c}-0.001496 * \\
(0.000810)\end{array}$ & $\begin{array}{c}0.001147 \\
(0.001602)\end{array}$ & $\begin{array}{c}0.000500 \\
(0.000956)\end{array}$ & $\begin{array}{c}0.000104 \\
(0.000749)\end{array}$ & $\begin{array}{c}0.001236 \\
(0.001379)\end{array}$ & $\begin{array}{c}0.000492 \\
(0.001951)\end{array}$ \\
\hline
\end{tabular}

from the GARCH model (7)-(8) of the WIG index returns.

Notes: (1) Values of standard errors in the brackets. (2) The number of the equation in the first column indicates whether the estimated parameters relate to the variables in the mean equation or in the conditional variance equation of the GARCH model. (3) Cells highlighted in grey indicate statistically significant estimates.

$*, * *, * *$ - denotes the significance at the $0.1,0.05,0.01$ level, respectively.

Source: authors' own calculations. 
Table $2 b$

Estimates of dummy variables for the NBP announcement days with announcement dummies in the conditional variance equation (10):

$$
h_{t}=\beta_{0}+\beta_{1} \xi_{t-1}^{2}+\beta_{2} h_{t-1}+\beta_{3} D U M_{t}
$$

from the GARCH model (9)-(10) of the WIG index volume of trade percentage changes and in the mean equation (11):

$$
\text { rvolume }_{t}=\alpha_{0}+\alpha_{1} r_{t-1}^{W I G}+\alpha_{2} D U M_{t}+\xi_{t}
$$

\begin{tabular}{|c|c|c|c|c|c|c|c|c|c|}
\hline Equation: & INTRATE & $M S$ & $R M$ & $B P M$ & $B P Q$ & OFRES & $A L$ & $F D E B T$ & $I I P$ \\
\hline & \multicolumn{9}{|c|}{ On day $t$} \\
\hline \multirow[t]{2}{*}{ (10) } & $\begin{array}{c}-21.72301 * * * \\
\quad(0.224246)\end{array}$ & $\begin{array}{c}-20.06964 * \\
(10.96046)\end{array}$ & $\begin{array}{c}-15.35968 * \\
(9.013646)\end{array}$ & $\begin{array}{c}-21.51831 * * \\
(9.075808)\end{array}$ & $\begin{array}{c}-21.48451 * * \\
(9.339183)\end{array}$ & $\begin{array}{c}-19.95279 * \\
(11.59621)\end{array}$ & $\begin{array}{c}-21.66414 * * \\
(9.099472)\end{array}$ & $\begin{array}{c}-21.56722 * * \\
(9.429649)\end{array}$ & $\begin{array}{c}-19.70750 * * \\
(8.983969)\end{array}$ \\
\hline & \multicolumn{9}{|c|}{ On day $t+1$} \\
\hline \multirow[t]{2}{*}{ (10) } & $\begin{array}{c}-21.39978 * * \\
(9.579289)\end{array}$ & $\begin{array}{c}-20.46349 * \\
(11.16105)\end{array}$ & $\begin{array}{c}-15.00750 * \\
(8.882115)\end{array}$ & $\begin{array}{c}-21.52862 * * \\
(8.633440)\end{array}$ & $\begin{array}{c}-17.72722 * \\
(9.403747)\end{array}$ & $\begin{array}{c}-21.30712 * \\
(12.43441)\end{array}$ & $\begin{array}{c}-20.75916 * \\
(12.50686)\end{array}$ & $\begin{array}{c}-17.91377 * \\
(9.461331)\end{array}$ & $\begin{array}{c}-17.75899 * * \\
(9.063967)\end{array}$ \\
\hline & \multicolumn{9}{|c|}{ On day $t$} \\
\hline \multirow[t]{2}{*}{ (11) } & $\begin{array}{l}-0.032334 \\
(0.826055)\end{array}$ & $\begin{array}{l}-0.095452 \\
(0.061145)\end{array}$ & $\begin{array}{l}-0.020649 \\
(0.058098)\end{array}$ & $\begin{array}{c}0.070303 \\
(0.077239)\end{array}$ & $\begin{array}{c}0.010594 \\
(0.080469)\end{array}$ & $\begin{array}{l}-0.042205 \\
(0.062316)\end{array}$ & $\begin{array}{c}-0.073862 \\
(0.055733)\end{array}$ & $\begin{array}{c}0.090900 \\
(0.101632)\end{array}$ & $\begin{array}{c}0.051854 \\
(0.130712)\end{array}$ \\
\hline & \multicolumn{9}{|c|}{ On day $t+1$} \\
\hline (11) & $\begin{array}{c}0.041585 \\
(0.089981)\end{array}$ & $\begin{array}{l}-0.045986 \\
(0.062792)\end{array}$ & $\begin{array}{c}0.026833 \\
(0.064422)\end{array}$ & $\begin{array}{l}-0.109296 \\
(0.072757)\end{array}$ & $\begin{array}{c}0.127818 \\
(0.226436)\end{array}$ & $\begin{array}{l}-0.038788 \\
(0.067048)\end{array}$ & $\begin{array}{l}-0.033570 \\
(0.080184)\end{array}$ & $\begin{array}{c}0.074383 \\
(0.208128)\end{array}$ & $\begin{array}{l}-0.149247 \\
(0.091640)\end{array}$ \\
\hline
\end{tabular}

from the GARCH model (11)-(12) of the WIG index volume of trade percentage changes

Notes: (1) Values of standard errors in the brackets. (2) The number of the equation in the first column indicates whether the estimated parameters relate to the variables in the mean equation or in the conditional variance equation of the GARCH model. (3) Cells highlighted in grey indicate statistically significant estimates.

$*, * *, * *$ - denotes the significance at the $0.1,0.05,0.01$ level, respectively.

Source: authors' own calculations. 
the conditional variance equation (10) from the GARCH model (9)-(10) of the WIG index volume of trade percentage changes. They show consistent evidence that on the day of the NBP communication the estimates of all 9 dummy variables had negative signs and they were all statistically significant (mainly at the 5\% level). A similar effect is observed on the following day when all the estimates also have negative signs and 8 out of 9 of them are statistically significant (however, mainly at the weaker 10\% level).

Overall, the results in Table $2 \mathrm{~b}$ can be interpreted as evidence supporting the existence of the calming effects of the NBP communication with financial markets by having an impact on the reduction of volatility of stock market activity measured by the conditional variance of the WIG index trading volume. This is an important finding of our study.

The effects of the NBP announcements on the changes of the WIG index trading volume are presented in the bottom two panels of Table $2 \mathrm{~b}$, which show the estimates of dummy variables for the NBP announcement days with announcement dummies in the mean equation (11) from the GARCH model (11)-(12) of the WIG index volume of trade percentage changes. In this case, no dummy is statistically significant, either on day $t$ or day $t+1$, which means that the release of the new macroeconomic figures by the NBP about its monetary policy did not affect the level of stock market activity.

\section{EMPIRICAL RESULTS: FOREIGN EXCHANGE MARKET}

In the next step, we discuss the models of the foreign exchange market returns and we analyze the models of foreign exchange market activity captured by the changes in the PLN/USD exchange rate bid-ask spread.

\subsection{Foreign exchange market returns}

Table $3 \mathrm{a}$ in the first two top panels presents the estimates of dummy variables for the NBP announcement days with announcement dummies in the conditional variance equation (16) from the GARCH model (15)-(16) of the PLN/USD exchange rate returns. On day $t$ the statistically significant effects were detected for two dummies, INTRATE and $M S$, and the same pattern of statistical significance was extended to day $t+1$. In all of those 4 cases the estimated parameters have consistently negative signs. The results in Table $3 \mathrm{a}$ confirm the findings from Table $2 \mathrm{a}$ about the existence of the calming effects of the NBP communication on the volatility of the stock 
market index returns (although they are weaker in the case of the foreign exchange returns models).

The bottom two panels in Table 3a present the estimates of dummy variables for the NBP announcement days with announcement dummies in the mean equation (19) from the GARCH model (19)-(20) of the PLN/USD exchange rate returns. They show that the PLN/USD exchange rate returns reacted statistically significantly to the NBP communication in 5 out of 9 cases on day $t$, i.e. in response to the INTRATE, MS, BPQ, FDEBT and IIP announcements, and in 1 case (the money supply $M S$ announcement) on day $t+1$. Similarly to the findings from the WIG index returns model presented in Table 2a, there is some evidence of the price reversal effects with estimates changing the sign between days $t$ and $t+1$, however this result is statistically significant for both those days only for the $M S$ dummy. ${ }^{6}$

\subsection{Foreign exchange market activity}

Next we discuss the models of the foreign exchange market activity measured by the PLN/USD exchange rate bid-ask spread.

Table $3 \mathrm{~b}$ in the first two top panels presents the estimates of dummy variables for the NBP announcement days with announcement dummies in the conditional variance equation (22) from the GARCH model (21)-(22) of the PLN/USD exchange rate bid-ask spread percentage changes. Similarly to the findings for the WIG index volume of trade from Table $2 \mathrm{~b}$, all the estimates are negative and all of them are statistically significant on day $t$ with further significance in 5 out of 9 cases on the following day $t+1$. This pattern of results additionally confirms the calming impact of the NBP communication of new monetary policy figures on the activity of the financial market.

Table $3 \mathrm{~b}$ in the bottom two panels shows the estimates of dummy variables for the NBP announcement days with announcement dummies in

\footnotetext{
${ }^{6}$ As in the case of the estimates from the bottom two panels in Table 2a, the results in the bottom two panels in Table 3a present the evidence about the general reaction of the foreign exchange market only to the announcement of the NBP data, regardless of the value of the new figures released by the NBP, so this finding indicates merely the scale of the currency market response to the NBP communication. However, we also analyzed in more detail the models with more disaggregated dummies for cases when interest rates were changed upwards and downwards and we found some interesting asymmetric effects (i.e. the reaction in both markets was statistically significant and the estimated parameters were negative when the interest rates were increased, but there was no statistical significance detected when the NBP has cut interest rates).
} 
Estimates of dummy variables for the NBP announcement days with announcement dummies in the conditional variance equation (16):

$$
h_{t}=\beta_{0}+\beta_{1} \xi_{t-1}^{2}+\beta_{2} h_{t-1}+\beta_{3} \text { rspread }_{t-1}+\beta_{4} D U M_{t}
$$

from the GARCH model (15)-(16) of the PLN/USD exchange rate returns and in the mean equation (19):

$$
r_{t}^{P L N / U S D}=\alpha_{0}+\alpha_{1} \text { rspread }_{t-1}+\alpha_{2} \text { DUM }_{t}+\xi_{t}
$$

\begin{tabular}{|c|c|c|c|c|c|c|c|c|c|}
\hline Equation: & INTRATE & $M S$ & $R M$ & $B P M$ & $B P Q$ & OFRES & $A L$ & $F D E B T$ & IIP \\
\hline & \multicolumn{9}{|c|}{ On day $t$} \\
\hline \multirow[t]{2}{*}{ (16) } & $\begin{array}{c}-2.73 \times 10^{-6} * * * \\
\left(3.93 \times 10^{-7}\right)\end{array}$ & $\begin{array}{c}-4.61 \times 10^{-6} * * * \\
\left(1.67 \times 10^{-6}\right)\end{array}$ & $\begin{array}{c}4.26 \times 10^{-6} \\
\left(5.62 \times 10^{-6}\right)\end{array}$ & $\begin{array}{r}6.37 \times 10^{-6} \\
\left(8.30 \times 10^{-6}\right) \\
\end{array}$ & $\begin{array}{c}2.29 \times 10^{-5} \\
\left(2.08 \times 10^{-5}\right) \\
\end{array}$ & $\begin{array}{r}1.54 \times 10^{-5} \\
\left(1.02 \times 10^{-5}\right)\end{array}$ & $\begin{array}{r}7.73 \times 10^{-6} \\
\left(4.91 \times 10^{-6}\right)\end{array}$ & $\begin{array}{l}8.62 \times 10^{-6} \\
\left(6.15 \times 10^{-6}\right) \\
\end{array}$ & $\begin{array}{l}-1.31 \times 10^{-6} \\
\left(5.99 \times 10^{-6}\right)\end{array}$ \\
\hline & \multicolumn{9}{|c|}{ On day $t+1$} \\
\hline \multirow[t]{2}{*}{ (16) } & $\begin{array}{c}-2.69 \times 10^{-5} * * \\
\left(2.54 \times 10^{-6}\right)\end{array}$ & $\begin{array}{c}-3.95 \times 10^{-6} * * * \\
\left(1.91 \times 10^{-8}\right)\end{array}$ & $\begin{array}{c}1.53 \times 10^{-5} \\
\left(9.51 \times 10^{-6}\right)\end{array}$ & $\begin{array}{r}3.72 \times 10^{-6} \\
\left(7.07 \times 10^{-6}\right) \\
\end{array}$ & $\begin{array}{c}3.66 \times 10^{-6} \\
\left(3.47 \times 10^{-6}\right) \\
\end{array}$ & $\begin{array}{r}1.52 \times 10^{-5} \\
\left(9.37 \times 10^{-6}\right)\end{array}$ & $\begin{array}{r}4.73 \times 10^{-6} \\
\left(4.72 \times 10^{-6}\right)\end{array}$ & $\begin{array}{c}7.02 \times 10^{-6} \\
\left(5.91 \times 10^{-6}\right)\end{array}$ & $\begin{array}{c}1.29 \times 10^{-6} \\
\left(6.51 \times 10^{-6}\right)\end{array}$ \\
\hline & \multicolumn{9}{|c|}{ On day $t$} \\
\hline \multirow[t]{2}{*}{ (19) } & $\begin{array}{c}-0.001807 * * * \\
(0.000672)\end{array}$ & $\begin{array}{c}-0.001039 * \\
(0.000542)\end{array}$ & $\begin{array}{c}0.000498 \\
(0.000701)\end{array}$ & $\begin{array}{l}-0.000599 \\
(0.000637)\end{array}$ & $\begin{array}{c}-0.003790 * * * \\
(0.001371)\end{array}$ & $\begin{array}{c}0.000505 \\
(0.000695) \\
\end{array}$ & $\begin{array}{l}-0.001046 \\
(0.000649)\end{array}$ & $\begin{array}{c}-0.003834 * * * \\
(0.001096)\end{array}$ & $\begin{array}{c}-0.005404 * * * \\
(0.001478)\end{array}$ \\
\hline & \multicolumn{9}{|c|}{ On day $t+1$} \\
\hline (19) & $\begin{array}{l}4.57 \times 10^{-5} \\
(0.000159)\end{array}$ & $\begin{array}{c}0.001763 * * * \\
(0.000620)\end{array}$ & $\begin{array}{l}-2.45 \times 10^{-5} \\
(0.000733)\end{array}$ & $\begin{array}{c}0.000437 \\
(0.000685)\end{array}$ & $\begin{array}{l}-0.000307 \\
(0.000961)\end{array}$ & $\begin{array}{c}6.50 \times 10^{-5} \\
(0.000735)\end{array}$ & $\begin{array}{c}0.000856 \\
(0.000559)\end{array}$ & $\begin{array}{c}0.000197 \\
(0.000933)\end{array}$ & $\begin{array}{c}0.001936 \\
(0.001277)\end{array}$ \\
\hline
\end{tabular}

from the GARCH model (19)-(20) of the PLN/USD exchange rate returns

Notes: (1) Values of the standard errors in the brackets. (2) The number of the equation in the first column indicates whether the estimated parameters relate to the variables in the mean equation or in the conditional variance equation of the GARCH model. (3) Cells highlighted in grey indicate statistically significant estimates.

$*, * *, * * *$-denotes the significance at the $0.1,0.05,0.01$ level, respectively.

Source: authors' own calculations. 
Table $3 b$

Estimates of dummy variables for the NBP announcement days with announcement dummies in the conditional variance equation (22):

$$
h_{t}=\beta_{0}+\beta_{1} \xi_{t-1}^{2}+\beta_{2} h_{t-1}+\beta_{3} D U M_{t}
$$

from the GARCH model (21)-(22) of the PLN/USD exchange rate bid-ask spread percentage changes and in the mean equation (23):

$$
\text { rspread }_{t}=\alpha_{0}+\alpha_{1} r_{t-1}^{P L N / U S D}+\alpha_{2} D U M_{t}+\xi_{t}
$$

\begin{tabular}{|c|c|c|c|c|c|c|c|c|c|}
\hline Equation: & INTRATE & $M S$ & $R M$ & $B P M$ & $B P Q$ & OFRES & $A L$ & FDEBT & IIP \\
\hline & \multicolumn{9}{|c|}{ On day $t$} \\
\hline \multirow[t]{2}{*}{ (22) } & $\begin{array}{c}-0.012133 * * * \\
(0.003082)\end{array}$ & $\begin{array}{c}-0.009721 * * * \\
(0.003602)\end{array}$ & $\begin{array}{c}-0.005463 * * \\
(0.002670)\end{array}$ & $\begin{array}{c}-0.0134477^{* * * *} \\
(0.003801)\end{array}$ & $\begin{array}{c}-0.024111 \text { *** } \\
(0.002889)\end{array}$ & $\begin{array}{c}-0.011765 * * * \\
(0.003388)\end{array}$ & $\begin{array}{c}-0.014061 * * * \\
(0.002815)\end{array}$ & $\begin{array}{c}-0.021333 * * * \\
(0.002474)\end{array}$ & $\begin{array}{c}-0.022203 * * * \\
(0.003700)\end{array}$ \\
\hline & \multicolumn{9}{|c|}{ On day $t+1$} \\
\hline \multirow[t]{2}{*}{ (22) } & $\begin{array}{c}-0.008278^{* * *} \\
(0.021316)\end{array}$ & $\begin{array}{r}-0.003614 \\
(0.005964)\end{array}$ & $\begin{array}{c}-0.003351 * * \\
(0.001529)\end{array}$ & $\begin{array}{c}-0.009699^{* *} * \\
(0.004847)\end{array}$ & $\begin{array}{c}-0.005887 * \\
(0.003544)\end{array}$ & $\begin{array}{c}-0.007805^{*} \\
(0.004690)\end{array}$ & $\begin{array}{c}0.000638 \\
(0.007571)\end{array}$ & $\begin{array}{c}0.000658 \\
(0.007401)\end{array}$ & $\begin{array}{c}-0.010903 * \\
(0.005996)\end{array}$ \\
\hline & \multicolumn{9}{|c|}{ On day $t$} \\
\hline \multirow[t]{2}{*}{ (23) } & $\begin{array}{c}0.007998 \\
(0.017961)\end{array}$ & $\begin{array}{c}-0.043341 \text { **** } \\
(0.009498)\end{array}$ & $\begin{array}{c}0.009929 \\
(0.011696)\end{array}$ & $\begin{array}{c}-0.027646 * \\
(0.016087)\end{array}$ & $\begin{array}{c}-0.030315 * * * \\
(0.008759)\end{array}$ & $\begin{array}{l}-0.017033 \\
(0.013737)\end{array}$ & $\begin{array}{c}-0.026163 * * * \\
(0.008794)\end{array}$ & $\begin{array}{c}-0.040536 * * * \\
(0.013205)\end{array}$ & $\begin{array}{c}-0.070262 * * \\
(0.031036)\end{array}$ \\
\hline & \multicolumn{9}{|c|}{ On day $t+1$} \\
\hline (23) & $\begin{array}{c}0.003888 \\
(0.021316)\end{array}$ & $\begin{array}{l}-0.011702 \\
(0.016821)\end{array}$ & $\begin{array}{c}0.015310 \\
(0.021083)\end{array}$ & $\begin{array}{l}-0.006722 \\
(0.017000)\end{array}$ & $\begin{array}{c}0.018516 \\
(0.031450)\end{array}$ & $\begin{array}{c}0.015129 \\
(0.016567)\end{array}$ & $\begin{array}{l}-0.003153 \\
(0.018252)\end{array}$ & $\begin{array}{c}0.041364 \\
(0.031040)\end{array}$ & $\begin{array}{l}-0.023420 \\
(0.033861)\end{array}$ \\
\hline
\end{tabular}

from the GARCH model (23)-(24) of the PLN/USD exchange rate bid-ask spread percentage changes.

Notes: (1) Values of standard errors in the brackets. (2) The number of the equation in the first column indicates whether the estimated parameters relate to the variables in the mean equation or in the conditional variance equation of the GARCH model. (3) Cells highlighted in grey indicate statistically significant estimates.

$*, * *, * * *$ - denotes the significance at the $0.1,0.05,0.01$ level, respectively.

Source: authors' own calculations. 
the mean equation (23) from the GARCH model (23)-(24) of the PLN/USD exchange rate bid-ask spread percentage changes. On day $t$ in 4 cases, for the $M S, B P Q, F D E B T$ and IIP dummies, the estimates are negative and statistically significant, which means that the release of the new NBP figures regarding those macroeconomic variables was associated with the narrowing of the bid-ask spread, suggesting an increase in the activity of the PLN/USD foreign exchange market. ${ }^{7}$ No estimate in the bottom two panels of Table $3 \mathrm{~b}$ which is statistically significant has a positive sign, so there is no evidence of the opposite effect, i.e. no evidence of a reduced impact on the level of the market activity of any of the NBP announcements.

In summary, the results in Tables $2 \mathrm{a}-2 \mathrm{~b}$ and $3 \mathrm{a}-3 \mathrm{~b}$ for the entire period between 2000 and 2012 show strong evidence about the existence of statistically significant results in variance, which we interpret as the calming effects of the NBP communication with financial markets, with further evidence about the additional effects in the mean.

\section{ADDITIONAL ROBUSTNESS ANALYSIS}

As further robustness checks, we estimated the versions of models where we controlled for the EUR/USD exchange rate returns as well as the interest rates differentials between the USA and Poland (in the foreign exchange market models) and the DJIA index returns (in the stock market models). The estimation results for the NBP announcement dummies were broadly the same and the inclusion of those control variables did not alter the whole picture.

As mentioned earlier in the methodological section, we followed Cheung and $\mathrm{Ng}$ (1996) and we adopted the approach that in all the models in our study the parameters for the dummy variables were estimated jointly (i.e. in one estimation for the mean equation and for the conditional variance equation). However, for comparison purposes we also estimated the parameters for all the dummy variables separately in the mean equations and separately in the conditional variance equations. ${ }^{8}$ The obtained estimates were very similar and they did not alter the overall picture, so we can

\footnotetext{
${ }^{7}$ These results are consistent with the findings from a recent study by Grabowski and Welfe (2016), who reported that fundamental factors, such as economic activity and the country's balance of payments, were important for explaining the currency movements (PLN/EUR) in the Polish foreign exchange market during the 2003-2013 period.

${ }^{8}$ These results are reported in the Appendix in Tables A2a, A2b, A3a and A3b.
} 
conclude that all our results are robust and they were not influenced by the effect described in Cheung and $\mathrm{Ng}$ (1996).

We also investigated the existence of the asymmetric effects in the ARCH class models which we estimated. We tested different alternative specifications (including EGARCH, GJR-GARCH etc.) and we found that the parameters capturing the asymmetries were in all cases not statistically significant. The estimates of other parameters were not affected in these variants of models either, so the sensitivity of our key parameters was very low and they were robust to the change of the functional form of the equations. The finding about asymmetric effects is consistent with the results in the ARCH literature. For example, Armitage and Brzeszczyński (2011), who in their study estimated a large number of ARCH class models and compared the best fitting variants, concluded that only less than $1 \%$ of all models was the asymmetric version (EGARCH in that instance) while there existed strong dominance of the GARCH specification (in particular: simple $\operatorname{GARCH}(1,1)$ model which was the best fitting variant in as many as $77 \%$ of all the cases among all the analyzed models).

Furthermore, we re-estimated our models under other, alternative, distributional assumptions, i.e. using the variants with Student's $t$ distribution, Student's $t$-distribution with fixed degrees of freedom, Generalized Error (GED) distribution and also Generalized Error (GED) distribution with fixed parameters. The results were very similar. As an example, in the first model presented in Table 2a the original estimate of the interest rate (INTRATE) dummy parameter under the normal distribution in the mean equation was: -0.002968 (p-value: 0.0563), whereas the estimates under the assumptions mentioned above were: 0.002639 (p-value: 0.0378 ), -0.002789 (p-value: 0.0272 ), -0.002401 (pvalue: 0.0577 ) and -0.002601 (p-value: 0.0410 ), respectively. Therefore, the differences in the estimated parameter were very small and the findings are qualitatively the same, i.e. they do not differ in terms of their statistical significance, sign of the estimated parameter or its magnitude. Similar results were obtained in the case of estimates of dummy variables in the conditional variance equations. ${ }^{9}$

\footnotetext{
9 Moreover, we attempted to investigate the evolution of the effects of the NBP announcements over time in shorter sub-samples, similarly to Brzeszczyński and Kutan (2015), however it was impossible to reach conclusive results due to numerical problems / convergence problems in ARCH models in such short sub-periods as well as because of the persistent heteroskedasticity and autocorrelation of the error term occurring in some cases.
} 


\section{DISCUSSION, POLICY IMPLICATIONS AND CONCLUSIONS}

The results presented in this study suggest that the NBP communication with financial markets in Poland significantly affected the investors' behaviour during our sample period in the years $2000-2012$. The main finding is that when the NBP announcement dummy variables are introduced in the conditional variance equations of the respective GARCH models, either for the WIG stock market index returns or the PLN/USD exchange rate returns, the conditional volatility of returns consistently declines in all the cases whenever any announcement was statistically significant. We interpret that phenomenon as the calming effect of public announcements of the new monetary policy figures released by the NBP. The evidence that conditional volatility had been reduced on the NBP announcement days suggests also that the NBP communication resulted in a decline of the uncertainty (measured here by the conditional variance) in the foreign exchange and stock markets. Our results further document the negative effects in variance in the models of the WIG index volume of trade and PLN/USD bid-ask spread, which suggests the existence of further calming effects of the NBP communication with financial markets on the changes of their activity.

Therefore, we can conclude that our evidence indicates that the NBP announcements had stabilizing effects on the stock and foreign exchange markets. In terms of the differences in the impact of the NBP communication on both market sectors, Tables A1a-A1c (in the Appendix) present a breakdown of the statistically significant estimation results for all the dummy variables from all the models reported in Tables $2 a-2 b$ and $3 a-3 b$.

Tables A1a-A1c show that the calming effect of the announcements appears to be quite similar in both markets with evidence of a slightly stronger influence in the stock market. As Table Ala illustrates, the NBP announcements of the monetary policy decisions had overall statistically significant effects in the variance equations in 26 cases on day $t$ and in 23 cases on day $t+1$, out of which they calmed stock market in 15 cases on day $t$ (and in 15 cases on day $t+1$ ) and they calmed the foreign exchange market in 11 cases on day $t$ (and in 8 cases on day $t+1$ ). Additional evidence about the impact of the NBP announcements in the mean equation of the WIG index returns and PLN/USD exchange rate returns models indicates the existence of wealth effects that potentially can be exploited by stock market and foreign exchange market investors.

The comparison of wealth effects between both markets (i.e. the results disaggregated in Tables A1b and A1c) shows stronger impact of the NBP 
communication in the foreign exchange market with 12 estimates of dummy variables statistically significant on days $t$ and $t+1$ (with 11 cases on day $t$ and one case on day $t+1$ ), while there is evidence about only 6 such cases in the stock market (with 4 cases on day $t$ and 2 cases on day $t+1$ ).

Overall, the reaction of both market sectors was stronger on day $t$ rather than on day $t+1$. As the data in Table Ala demonstrates, there are 41 cases when estimates of dummy variables for the NBP communication events were statistically significant on day $t$ and only 26 such cases on day $t+1$. When the estimation results are analyzed by the individual types of announcements, the publication of the new money supply $(M S)$ data appears to be the most relevant news: the estimate of the $M S$ dummy variable is statistically significant most often, i.e. in 12 cases (including 7 times on day $t$ and 5 times on the following day $t+1)$. The next most frequently significant announcements are interest rate (INTRATE), which is significant in 10 cases (6 times on day $t$ and 4 times on day $t+1$ ) and international investment position (IIP) with 9 cases significant in all models (including 6 times on day $t$ and 3 times on day $t+1$ ). The numbers for all the announcements in all models are summarized in Table Ala.

This pattern of greatest significance of money supply announcements is also consistent across all the models for the stock market and for the foreign exchange market reported in more detail in Table A1b and Table A1c. Therefore, it appears that investors in both market segments react with the highest sensitivity to the monetary policy news captured, in particular, by changes in the new money supply data revealed by the NBP.

The results reported in this study broadly confirm the findings presented by Brzeszczyński and Kutan (2015), who also reported that the NBP communication with financial markets significantly affected investor behaviour during the early years of their sample period of 2000-2003. Similarly to Brzeszczyński and Kutan (2015), we provided evidence, based on an extended data sample until the year 2012 and using more types of the NBP announcements, that the NBP news helped reduce stock and foreign exchange markets' uncertainty and also had some positive effects on the increase of activity in the foreign exchange market (which we measured by the changes in the PLN/USD bid-ask spread). Our findings demonstrate further the existence of the wealth effects, which were initially identified by Brzeszczyński and Kutan (2015) in the foreign exchange market. In this study, we report more results which document such effects also in the stock market. 
The findings from our analysis imply that the National Bank of Poland has consistently influenced the financial markets: not only during the early years, when it gained its independence, but also during the later years. Such result suggests that the NBP is an important player in affecting domestic financial markets and that investors need to pay attention to the policy announcements, which the NBP releases on a regular basis. This fact, in turn, has important implications for portfolio managers in relation to the design of effective strategies aiming to protect investors' wealth.

Regarding the broader policy implications of our findings, the results suggest that central banks communication in the newly emerging European economies can generate wealth and volatility (risk) effects, so the investors need to watch their actions carefully to make effective strategic investment decisions. In addition, central bankers need to conduct a transparent communication policy to minimize uncertainty and to reduce market risk.

Our results also have some theoretical implications, in particular regarding the understanding of the transmission channels of monetary policy to asset markets. Our findings imply that central bank communication can be an important and effective monetary policy transmission mechanism and it can work through the asset markets indeed. Finally, the results from this study suggest that the release of public information contained in central bank communication can affect asset prices, which supports the predictions of theoretical exchange rate models that emphasize the importance of the arrival of public information for price discovery.

\section{REFERENCES}

Andritzky, J., Bannister J. G., Tamirisa, N., The Impact of Macroeconomic Announcements on Emerging Market Bonds, "Emerging Markets Review" 8, pp. 20-37, 2007.

Armitage, S., Brzeszczyński, J., Heteroskedasticity and Interval Effects in Estimating Beta: UK Evidence, “Applied Financial Economics” 21, pp. 1525-1538, 2011.

Baranowski, P., Gajewski, P., Credible Enough? Forward Guidance and Perceived National Bank of Poland's Policy Rule, "Applied Economics Letters" 23, pp. 89-92, 2016.

Bastidon, C., Huchet, N., Kocoglu, Y., Unconventional Monetary Policy in the Eurozone: A Lack of Forward Guidance?, "Emerging Markets Finance and Trade" 52, pp. 76-97, 2016.

Będowska-Sójka, B., Liquidity Dynamics Around Jumps: The Evidence from the Warsaw Stock Exchange, "Emerging Markets Finance and Trade" 52, pp. 2740-2755, 2016.

Bollerslev, T., Generalized Autoregressive Conditional Heteroskedasticity, "Journal of Econometrics" 31, pp. 307-327, 1986. 
Büttner, D., Hayo, B., EMU-related News and Financial Markets in the Czech Republic, Hungary and Poland, "Applied Economics" 44, pp. 4037-4053, 2012.

Brzeszczyński, J., Kutan, M. A., Public Information Arrival and Investor Reaction During a Period of Institutional Change: An Episode of Early Years of a Newly Independent Central Bank, "Journal of Comparative Economics" 43, pp. 727-753, 2015.

Brzeszczyński, J., Gajdka, J., Kutan, M. A., Investor Response to Public News, Sentiment and Institutional Trading in Emerging Markets: A Review, "International Review of Economics and Finance" 40, pp. 338-352, 2015.

Brzeszczyński, J., Melvin, M., "Explaining Trading Volume in the Euro", International Journal of Finance and Economics 11, pp. 25-34, 2006.

Cheung, Y.-W., Ng, K. L., A Causality-in-Variance Test and Its Application to Financial Market Prices, "Journal of Econometrics" 72, pp. 33-48, 1996.

Engle, R. F., Autoregressive Conditional Heteroskedasticity with Estimates of the Variance of United Kingdom Inflation, "Econometrica" 50, pp. 987-1008, 1982.

Fact Book, Warsaw Stock Exchange, Warsaw, 2013.

Filipowicz, E., Assessment of the Reaction Stock Returns to the Changes in the Open Market Operation Rate. Conditional Event Study Analysis, "Ruch Prawniczy, Ekonomiczny i Socjologiczny" 75, pp. 187-200, 2013.

Frömmel, M., Han, X., Gysegem, V. F., Further Evidence on Foreign Exchange Jumps and News Announcements, "Emerging Markets Finance and Trade" 51, pp. 774-787, 2015.

Ganapolsky, E. J. J., Schmuckler, L. S., Crisis Management in Argentina During the 19941995 Mexican Crisis: How Did Markets React? [in:] Devarajan, S., Rogers, F., Squire, L. (eds.), "World Bank Economists' Forum”, Vol. 1, 3-30, 2001.

Gómez, M., Melvin, M., Nardari, F., Explaining the Early Years of the Euro Exchange Rate: An Episode of Learning about a New Central Bank, "European Economic Review" 51, pp. 505-520, 2006.

Grabowski, W., Welfe, A., An Exchange Rate Model with Market Pressures and a Contagion Effect, "Emerging Markets Finance and Trade" 52, pp. 2706-2720, 2016.

Hanousek, J., Kočenda, E., Kutan, M. A., The Reaction of Asset Prices to Macroeconomic Announcements in New EU markets: Evidence from Intraday Data, "Journal of Financial Stability" 5, pp. 199-219, 2009.

Hausman, J., Wongswan, J., Global Asset Prices and FOMC Announcements, "Journal of International Money and Finance" 30, pp. 547-571, 2011.

Janecki, J., Reakcja rynkowych stóp procentowych na zmiany stopy procentowej banku centralnego $w$ Polsce $w$ latach 2001-2011 [Reactions of market interest rates to the changes of central bank's interest rate in Poland in years 2001-2011], „Materiały i Studia NBP”, Zeszyt nr 272, Narodowy Bank Polski, Warszawa, 2012.

Kaminsky, G., Schmukler, L. S., Emerging Market Instability: Do Sovereign Ratings Affect Country Risk and Stock Returns?, "World Bank Economic Review" 16, pp. 171-195, 2002.

Kapuściński, M., Łyziak, T., Przystupa, J., Stanisławska, E., Sznajderska, A., Wróbel, E., Mechanizm transmisji polityki pieniężnej w Polsce. Co wiemy w 2013 roku? [Monetary 
policy transmission mechanism in Poland. What do we know in the year 2013?], „Materiały i Studia NBP”, Zeszyt nr 306, Narodowy Bank Polski, Warszawa, 2014.

Korczak, P., Bohl, T. M., Empirical Evidence on Cross-listed Stocks of Central and Eastern European Companies, "Emerging Markets Review" 6, pp. 121-137, 2005.

Kubacki, D., Comparison of the Information Efficiency of the Financial Markets in Selected European Union Countries on the Event 'Central Bank Information About Changing or Not Changing the Level of the Reference Rate, "Journal of Management and Financial Sciences" 7, pp. 75-92, 2014.

Loiseau-Aslanidi, O., Determinants and Effectiveness of Foreign Exchange Market Intervention in Georgia, "Emerging Markets Finance and Trade" 47, pp. 75-95, 2011.

Marquardt, D. W., An Algorithm for Least Squares Estimation of Nonlinear Parameters, "Journal of the Society for Industrial and Applied Mathematics" 11, pp. 431-441, 1963.

Nikkinen, J., Omran, M., Sahlström, P., Äijö, J., Global Stock Market Reactions to Scheduled U.S. Macroeconomic News Announcements, “Global Finance Journal” 17, pp. 92-104, 2006.

Poghosyan, T., Kočenda, E., Zemčik, P., Modelling Foreign Exchange Risk Premium in Armenia, "Emerging Markets Finance and Trade" 44, pp. 41-61, 2008.

Robitaille, P., Roush, J., How Do FOMC Actions and U.S. Macroeconomic Data Announcements Move Brazilian Sovereign Yield Spreads and Stock Prices?, "International Finance Discussion Papers” No. 868, Federal Reserve Board, Washington D. C., 2006.

Rozkrut, M., Rybiński, K., Sztaba, L., Szwaja, R., Quest for Central Bank Communication: Does it Pay to Be 'Talkative'?, "European Journal of Political Economy" 23, pp. 176-206, 2007.

Saba, K., Kudła, J., (2014), Wpływ zmian stopy referencyjnej NBP na zmiany wartości i zmienność indeksu WIG20 [The impact of the NBP reference rate changes on the variability of the value and on the volatility of the WIG20 index], „Ekonomia” 24, 105-125.

Serwa, D., Do Emerging Financial Markets React to Monetary Policy Announcements? Evidence from Poland, "Applied Financial Economics" 16, pp. 513-523, 2006.

Triennial Central Bank Survey. Foreign Exchange and Derivatives Market Activity in 2007, Bank for International Settlements, Basel, December 2007.

Triennial Central Bank Survey. Report on Global Foreign Exchange Market Activity in 2010, Bank for International Settlements, Basel, December 2010.

Triennial Central Bank Survey. Foreign Exchange Turnover in April 2013, Bank for International Settlements, Basel, September 2013.

Triennial Central Bank Survey. Foreign Exchange Turnover in April 2016, Bank for International Settlements, Basel, September 2016.

Włodarczyk, T., Wpływ wypowiedzi i komentarzy członków Rady Polityki Pieniężnej na krzywa dochodowości. Badanie pótsilnej efektywności informacyjnej rynku kontraktów FRA $i$ swapów procentowych [The influence of the statements and the comments of the Monetary Policy Council members on the yield curve. The analysis of the semi-strong informational efficiency of the FRA contracts market and the interest rate swaps], „Bank i Kredyt” 2, pp. 43-59, 2008. 
Wongswan, J., The Response of Global Equity Indexes to U.S. Monetary Policy Announcements, "Journal of International Money and Finance" 28, pp. 344-365, 2009.

Ziarko-Siwek, U., Ocena efektywności informacyjnej wybranych segmentów rynku finansowego $w$ Polsce [Evaluation of the informational efficiency of the selected segments of the financial market in Poland], „Materiały i Studia NBP”, Zeszyt nr 178, Narodowy Bank Polski, Warszawa, 2004.

Received: October 2014, revised: April 2017

Acknowledgements: We would like to thank the participants of the International Conference on Neoclassical and Behavioural Finance in Lódź on 26-27 June 2014, the participants of the British Accounting and Finance Association (BAFA) NAG conference in Newcastle-upon-Tyne on 8-9 September 2014 and the participants of the conference INWEST '2014 in Wroctaw on 17-19 September 2014 for their comments on this paper.

We are also grateful to Christian Hansen, Jeffrey Wooldridge, Michael Melvin and Mark Schaffer for very helpful discussion regarding some of the key econometric issues in our study as well as to the officials at the NBP for providing to us very detailed information about the NBP announcements.

The financial support from the National Bank of Poland from the research grant: "Transparency of the National Bank of Poland (NBP) communication strategy with financial markets and the impact of publication of key information about the NBP monetary policy on the reaction of the foreign exchange market and stock market" in the year 2013 is gratefully acknowledged. 
Table A1a

Numbers of statistically significant estimates of dummy variables for the NBP announcements in all models

\begin{tabular}{|c|c|c|c|c|c|c|c|c|c|c|}
\hline Equation: & INTRATE & $M S$ & $R M$ & $B P M$ & $B P Q$ & OFRES & $A L$ & FDEBT & $I I P$ & Sum: \\
\hline & \multicolumn{10}{|c|}{ On day $t$} \\
\hline Mean equation & 2 & 3 & 0 & 1 & 2 & 0 & 1 & 3 & 3 & 15 \\
\hline Variance equation & 4 & 4 & 2 & 3 & 2 & 2 & 3 & 3 & 3 & 26 \\
\hline \multirow[t]{2}{*}{ Sum for day $t$ : } & 6 & 7 & 2 & 4 & 4 & 2 & 4 & 6 & 6 & 41 \\
\hline & \multicolumn{10}{|c|}{ On day $t+1$} \\
\hline Mean equation & 0 & 2 & 0 & 1 & 0 & 0 & 0 & 0 & 0 & 3 \\
\hline Variance equation & 4 & 3 & 2 & 3 & 2 & 2 & 2 & 2 & 3 & 23 \\
\hline \multirow[t]{2}{*}{ Sum for day $t+1$ : } & 4 & 5 & 2 & 4 & 2 & 2 & 2 & 2 & 3 & 26 \\
\hline & \multicolumn{10}{|c|}{ On days $t$ and $t+1$} \\
\hline $\begin{array}{c}\text { Sum for days } t \\
\text { and } t+1:\end{array}$ & 10 & 12 & 4 & 8 & 6 & 4 & 6 & 8 & 9 & 67 \\
\hline
\end{tabular}

Note: This table provides a summary of all the estimates from Tables $2 a-2 b$ and $3 a-3 b$

Source: authors' own calculations. 


\section{Table A1b}

Numbers of statistically significant estimates of dummy variables for the NBP announcements in the stock market models

\begin{tabular}{|c|c|c|c|c|c|c|c|c|c|c|}
\hline Equation: & INTRATE & $M S$ & $R M$ & $B P M$ & $B P Q$ & OFRES & $A L$ & FDEBT & IIP & Sum: \\
\hline & \multicolumn{10}{|c|}{ On day $t$} \\
\hline Mean equation & 1 & 1 & 0 & 0 & 0 & 0 & 0 & 1 & 1 & 4 \\
\hline Variance equation & 2 & 2 & 1 & 2 & 1 & 1 & 2 & 2 & 2 & 15 \\
\hline \multirow[t]{2}{*}{ Sum for day $t$ : } & 3 & 3 & 1 & 2 & 1 & 1 & 2 & 3 & 3 & 19 \\
\hline & \multicolumn{10}{|c|}{ On day $t+1$} \\
\hline Mean equation & 0 & 1 & 0 & 1 & 0 & 0 & 0 & 0 & 0 & 2 \\
\hline Variance equation & 2 & 2 & 1 & 2 & 1 & 1 & 2 & 2 & 2 & 15 \\
\hline \multirow[t]{2}{*}{ Sum for day $t+1$ : } & 2 & 3 & 1 & 3 & 1 & 1 & 2 & 2 & 2 & 17 \\
\hline & \multicolumn{10}{|c|}{ On days $t$ and $t+1$} \\
\hline $\begin{array}{l}\text { Sum for days } t \\
\text { and } t+1:\end{array}$ & 5 & 6 & 2 & 5 & 2 & 2 & 4 & 5 & 5 & 36 \\
\hline
\end{tabular}

Note: This table provides a summary of the estimates from Tables $2 a-2 b$

Source: authors' own calculations. 
Table Alc

Numbers of statistically significant estimates of dummy variables for the NBP announcements in the foreign exchange market models

\begin{tabular}{|c|c|c|c|c|c|c|c|c|c|c|}
\hline Equation: & INTRATE & $M S$ & $R M$ & $B P M$ & $B P Q$ & OFRES & $A L$ & FDEBT & $I I P$ & Sum: \\
\hline & \multicolumn{9}{|c|}{ On day $t$} & \\
\hline Mean equation & 1 & 2 & 0 & 1 & 2 & 0 & 1 & 2 & 2 & 11 \\
\hline Variance equation & 2 & 2 & 1 & 1 & 1 & 1 & 1 & 1 & 1 & 11 \\
\hline \multirow[t]{2}{*}{ Sum for day $t:$} & 3 & 4 & 1 & 2 & 3 & 1 & 2 & 3 & 3 & 22 \\
\hline & \multicolumn{9}{|c|}{ On day $t+1$} & \\
\hline Mean equation & 0 & 1 & 0 & 0 & 0 & 0 & 0 & 0 & 0 & 1 \\
\hline Variance equation & 2 & 1 & 1 & 1 & 1 & 1 & 0 & 0 & 1 & 8 \\
\hline \multirow[t]{2}{*}{ Sum for day $t+1$ : } & 2 & 2 & 1 & 1 & 1 & 1 & 0 & $\mathbf{0}$ & 1 & 9 \\
\hline & \multicolumn{10}{|c|}{ On days $t$ and $t+1$} \\
\hline $\begin{array}{l}\text { Sum for days } t \\
\text { and } t+1:\end{array}$ & 5 & 6 & 2 & 3 & 4 & 2 & 2 & 3 & 4 & 31 \\
\hline
\end{tabular}

Note: This table provides a summary of the estimates from Tables $3 a-3 b$

Source: authors' own calculations. 


\section{Table A2a}

Estimates of dummy variables for the NBP announcement days with announcement dummies in the conditional variance equation (4):

$$
h_{t}=\beta_{0}+\beta_{1} \xi_{t-1}^{2}+\beta_{2} h_{t-1}+\beta_{3} \text { rvolume }_{t-1}+\beta_{4} D U M_{t}
$$

from the GARCH model (3) (4) of the WIG index returns and in the mean equation (7):

$$
r_{t}^{\text {WTG }}=\alpha_{0}+\alpha_{1} \text { rvolume }_{t-1}+\alpha_{2} \text { DUM }_{t}+\xi_{t}
$$

from the GARCH model (7)-(8) of the WIG index returns (results from separate estimations of parameters in the mean equation and in the

\begin{tabular}{|c|c|c|c|c|c|c|c|c|c|}
\hline Equation: & INTRATE & $M S$ & $R M$ & $B P M$ & $B P Q$ & OFRES & $A L$ & FDEBT & IIP \\
\hline & \multicolumn{9}{|c|}{ On day $t$} \\
\hline \multirow[t]{2}{*}{ (4) } & $\begin{array}{c}-1.93 \times 10^{-5} * * \\
\left(9.35 \times 10^{-6}\right)\end{array}$ & $\begin{array}{c}-2.32 \times 10^{-5 * * *} \\
\left(7.92 \times 10^{-6}\right)\end{array}$ & $\begin{array}{c}1.03 \times 10^{-5} \\
\left(9.64 \times 10^{-6}\right)\end{array}$ & $\begin{array}{c}-1.57 \times 10^{-5} * * \\
\left(6.19 \times 10^{-6}\right)\end{array}$ & $\begin{array}{c}1.43 \times 10^{-5} \\
\left(1.45 \times 10^{-6}\right)\end{array}$ & $\begin{array}{c}1.17 \times 10^{-5} \\
\left(9.73 \times 10^{-6}\right)\end{array}$ & $\begin{array}{c}-2.05 \times 10^{-5} * * \\
\left(8.30 \times 10^{-6}\right)\end{array}$ & $\begin{array}{c}-3.62 \times 10^{-5} * * * \\
\left(1.31 \times 10^{-5}\right)\end{array}$ & $\begin{array}{c}-3.11 \times 10^{-5} * \\
\left(1.81 \times 10^{-5}\right)\end{array}$ \\
\hline & \multicolumn{9}{|c|}{ On day $t+1$} \\
\hline \multirow[t]{2}{*}{ (4) } & $\begin{array}{l}-1.06 \times 10^{-5} \\
\left(9.78 \times 10^{-6}\right)\end{array}$ & $\begin{array}{c}-5.66 \times 10^{-7} * * \\
\left(2.58 \times 10^{-7}\right)\end{array}$ & $\begin{array}{c}1.51 \times 10^{-5} \\
\left(1.09 \times 10^{-5}\right)\end{array}$ & $\begin{array}{l}-2.06 \times 10^{-5} \\
\left(9.04 \times 10^{-6}\right)\end{array}$ & $\begin{array}{c}7.59 \times 10^{-6} \\
\left(1.29 \times 10^{-5}\right)\end{array}$ & $\begin{array}{c}1.55 \times 10^{-5} \\
\left(1.09 \times 10^{-5}\right)\end{array}$ & $\begin{array}{l}-3.48 \times 10^{-5} \\
\left(9.95 \times 10^{-6}\right)\end{array}$ & $\begin{array}{c}-3.15 \times 10^{-5} * * \\
\left(1.48 \times 10^{-5}\right)\end{array}$ & $\begin{array}{l}-3.47 \times 10^{-5} \\
\left(1.28 \times 10^{-5}\right)\end{array}$ \\
\hline & \multicolumn{9}{|c|}{ On day $t$} \\
\hline \multirow[t]{2}{*}{ (7) } & $\begin{array}{c}-0.002873 * \\
(0.001579)\end{array}$ & $\begin{array}{c}-0.001544 * \\
(0.000912)\end{array}$ & $\begin{array}{l}-0.000490 \\
(0.000955)\end{array}$ & $\begin{array}{c}0.000402 \\
(0.000901)\end{array}$ & $\begin{array}{l}-0.000718 \\
(0.001606)\end{array}$ & $\begin{array}{l}-0.000504 \\
(0.000970)\end{array}$ & $\begin{array}{c}0.000753 \\
(0.000864)\end{array}$ & $\begin{array}{l}-0.002176 \\
(0.001371)\end{array}$ & $\begin{array}{c}-0.003531 * \\
(0.001900)\end{array}$ \\
\hline & \multicolumn{9}{|c|}{ On day $t+1$} \\
\hline (7) & $\begin{array}{c}0.000785 \\
(0.001513)\end{array}$ & $\begin{array}{l}0.001558 * \\
(0.000910)\end{array}$ & $\begin{array}{c}0.000579 \\
(0.000962)\end{array}$ & $\begin{array}{c}-0.001569 * \\
(0.000815)\end{array}$ & $\begin{array}{c}0.001201 \\
(0.001593)\end{array}$ & $\begin{array}{c}0.000521 \\
(0.000949)\end{array}$ & $\begin{array}{l}-0.000233 \\
(0.000774)\end{array}$ & $\begin{array}{c}0.000821 \\
(0.001470)\end{array}$ & $\begin{array}{l}-0.000922 \\
(0.002109)\end{array}$ \\
\hline
\end{tabular}
conditional variance equation)

Notes: (1) Values of the standard errors in the brackets. (2) The number of the equation in the first column indicates whether the estimated parameters relate to the variables in the mean equation or in the conditional variance equation of the GARCH model. (3) Cells highlighted in grey indicate statistically significant estimates.

$*, * *, * * *$ - denotes the significance at the $0.1,0.05,0.01$ level, respectively

Source: authors' own calculations. 
Table A2b

Estimates of dummy variables for the NBP announcement days with announcement dummies in the conditional variance equation (10):

$$
h_{t}=\beta_{0}+\beta_{1} \xi_{t-1}^{2}+\beta_{2} h_{t-1}+\beta_{3} D U M_{t}
$$

from the GARCH model (9)-(10) of the WIG index volume of trade percentage changes and in the mean equation (11):

$$
\text { rvolume }{ }_{t}=\alpha_{0}+\alpha_{1} r_{t-1}^{W I G}+\alpha_{2} D U M_{t}+\xi_{t}
$$

from the GARCH model (11)-(12) of the WIG index volume of trade percentage changes (results from separate estimations of parameters in

\begin{tabular}{|c|c|c|c|c|c|c|c|c|c|}
\hline Equation: & INTRATE & $M S$ & $R M$ & $B P M$ & $B P Q$ & OFRES & $A L$ & $F D E B T$ & $I I P$ \\
\hline & \multicolumn{9}{|c|}{ On day $t$} \\
\hline \multirow[t]{2}{*}{ (10) } & $\begin{array}{c}-20.24637 * * \\
(9.143042)\end{array}$ & \begin{tabular}{|c|}
$-20.49359 * *$ \\
$(10.03915)$ \\
\end{tabular} & $\begin{array}{c}-14.33467 * \\
(8.375619)\end{array}$ & $\begin{array}{c}-21.14613 * * \\
(8.942810)\end{array}$ & $\begin{array}{c}-18.49429 * * \\
(9.206042)\end{array}$ & $\begin{array}{c}-21.67576 * * \\
(9.430969)\end{array}$ & $\begin{array}{c}-19.86440 * \\
(10.24098)\end{array}$ & $\begin{array}{c}-16.21634 * \\
(9.468795)\end{array}$ & $\begin{array}{c}-16.68194 * \\
(8.921365)\end{array}$ \\
\hline & \multicolumn{9}{|c|}{ On day $t+1$} \\
\hline \multirow[t]{2}{*}{ (10) } & $\begin{array}{c}-20.08276 * * \\
(9.515100)\end{array}$ & $\begin{array}{c}-20.29380 * * \\
(9.924993)\end{array}$ & $\begin{array}{c}-13.52971 * \\
(7.000854)\end{array}$ & $\begin{array}{c}-18.64986 * * \\
(8.981483)\end{array}$ & $\begin{array}{c}-16.90903 * \\
(10.03036)\end{array}$ & $\begin{array}{c}-20.21022 * \\
(11.92870)\end{array}$ & $\begin{array}{c}-21.20971 * \\
(12.53491)\end{array}$ & $\begin{array}{l}-14.63674 \\
(9.469696)\end{array}$ & $\begin{array}{c}-14.67462 * \\
(8.705323)\end{array}$ \\
\hline & \multicolumn{9}{|c|}{ On day $t$} \\
\hline \multirow[t]{2}{*}{ (11) } & $\begin{array}{l}-0.035989 \\
(0.072261)\end{array}$ & $\begin{array}{l}-0.167229 \\
(0.129184)\end{array}$ & $\begin{array}{c}-0.034768 \\
(0.253333)\end{array}$ & $\begin{array}{c}0.023848 \\
(0.254591)\end{array}$ & $\begin{array}{c}0.039462 \\
(0.503992)\end{array}$ & $\begin{array}{l}-0.033713 \\
(0.253334)\end{array}$ & $\begin{array}{l}-0.068110 \\
(0.254209)\end{array}$ & $\begin{array}{c}0.093219 \\
(0.477746)\end{array}$ & $\begin{array}{c}0.090114 \\
(0.649556)\end{array}$ \\
\hline & \multicolumn{9}{|c|}{ On day $t+1$} \\
\hline (11) & $\begin{array}{c}0.101746 \\
(0.090514)\end{array}$ & $\begin{array}{l}-0.032874 \\
(0.070756)\end{array}$ & $\begin{array}{c}0.021158 \\
(0.253391)\end{array}$ & $\begin{array}{l}-0.109850 \\
(0.254385)\end{array}$ & $\begin{array}{c}0.144733 \\
(0.504058)\end{array}$ & $\begin{array}{c}0.022099 \\
(0.253392)\end{array}$ & $\begin{array}{l}-0.041390 \\
(0.254297)\end{array}$ & $\begin{array}{c}0.094138 \\
(0.477792)\end{array}$ & $\begin{array}{l}-0.142663 \\
(0.649405)\end{array}$ \\
\hline
\end{tabular}
the mean equation and in the conditional variance equation)

Notes: (1) Values of the standard errors in the brackets. (2) The number of the equation in the first column indicates whether the estimated parameters relate to the variables in the mean equation or in the conditional variance equation of the GARCH model. (3) Cells in grey indicate statistically significant estimates.

$*, * *, * *$ - denotes the significance at the $0.1,0.05,0.01$ level, respectively.

Source: authors' own calculations. 


\section{Table A3a}

Estimates of dummy variables for the NBP announcement days with announcement dummies in the conditional variance equation (16):

$$
h_{t}=\beta_{0}+\beta_{1} \xi_{t-1}^{2}+\beta_{2} h_{t-1}+\beta_{3} \text { rspread }_{t-1}+\beta_{4} \text { DUM }_{t}
$$

from the GARCH model (15)-(16) of the PLN/USD exchange rate returns and in the mean equation (19):

$$
r_{t}^{P L N / U S D}=\alpha_{0}+\alpha_{1} \text { rspread }_{t-1}+\alpha_{2} D U M_{t}+\xi_{t}
$$

from the GARCH model (19)-(20) of the PLN/USD exchange rate returns (results from separate estimations of parameters in the mean

\begin{tabular}{|c|c|c|c|c|c|c|c|c|c|}
\hline Equation: & INTRATE & $M S$ & $R M$ & $B P M$ & $B P Q$ & OFRES & $A L$ & $F D E B T$ & IIP \\
\hline & \multicolumn{9}{|c|}{ On day $t$} \\
\hline \multirow[t]{2}{*}{ (16) } & $\begin{array}{c}-2.36 \times 10^{-6} * * \\
\left(1.06 \times 10^{-6}\right)\end{array}$ & $\begin{array}{c}-5.36 \times 10^{-6} * * * \\
\left(2.00 \times 10^{-6}\right)\end{array}$ & $\begin{array}{c}1.43 \times 10^{-5} \\
\left(1.15 \times 10^{-5}\right)\end{array}$ & $\begin{array}{r}6.91 \times 10^{-6} \\
\left(5.15 \times 10^{-6}\right)\end{array}$ & $\begin{array}{c}4.54 \times 10^{-5} \\
\left(2.91 \times 10^{-5}\right)\end{array}$ & $\begin{array}{r}1.57 \times 10^{-5} \\
\left(1.37 \times 10^{-5}\right)\end{array}$ & $\begin{array}{c}7.29 \times 10^{-6} \\
\left(5.00 \times 10^{-6}\right)\end{array}$ & $\begin{array}{c}2.63 \times 10^{-6} \\
\left(1.94 \times 10^{-6}\right)\end{array}$ & $\begin{array}{r}1.34 \times 10^{-5} \\
\left(1.16 \times 10^{-6}\right)\end{array}$ \\
\hline & \multicolumn{9}{|c|}{ On day $t+1$} \\
\hline \multirow[t]{2}{*}{ (16) } & $\begin{array}{c}-2.19 \times 10^{-5} * * * \\
\left(2.29 \times 10^{-6}\right)\end{array}$ & $\begin{array}{c}-3.67 \times 10^{-6} * * * \\
\left(1.27 \times 10^{-6}\right)\end{array}$ & $\begin{array}{l}-1.80 \times 10^{-6} \\
\left(1.16 \times 10^{-6}\right)\end{array}$ & $\begin{array}{r}4.73 \times 10^{-6} \\
\left(4.83 \times 10^{-6}\right)\end{array}$ & $\begin{array}{l}-6.52 \times 10^{-7} \\
\left(6.93 \times 10^{-7}\right)\end{array}$ & $\begin{array}{r}1.53 \times 10^{-5} \\
\left(9.48 \times 10^{-5}\right)\end{array}$ & $\begin{array}{r}3.89 \times 10^{-6} \\
\left(4.63 \times 10^{-6}\right)\end{array}$ & $\begin{array}{c}6.62 \times 10^{-6} \\
\left(5.93 \times 10^{-6}\right)\end{array}$ & $\begin{array}{l}-7.63 \times 10^{-6} \\
\left(8.07 \times 10^{-6}\right)\end{array}$ \\
\hline & \multicolumn{9}{|c|}{ On day $t$} \\
\hline \multirow[t]{2}{*}{ (19) } & $\begin{array}{c}-0.001500 * \\
(0.000768)\end{array}$ & $\begin{array}{c}-0.001050 * \\
(0.000568)\end{array}$ & $\begin{array}{c}0.000499 \\
(0.000728)\end{array}$ & $\begin{array}{l}-0.000744 \\
(0.000664)\end{array}$ & $\begin{array}{c}-0.003929 * * * \\
(0.001108)\end{array}$ & $\begin{array}{c}0.000442 \\
(0.000652)\end{array}$ & $\begin{array}{l}-0.001013 \\
(0.000641)\end{array}$ & $\begin{array}{c}-0.003768 * * * \\
(0.001021)\end{array}$ & $\begin{array}{c}-0.005359 * * * \\
(0.001544)\end{array}$ \\
\hline & \multicolumn{9}{|c|}{ On day $t+1$} \\
\hline (19) & $\begin{array}{l}-0.000591 \\
(0.000626)\end{array}$ & $\begin{array}{c}0.001989 * * * \\
(0.000603)\end{array}$ & $\begin{array}{l}-0.000133 \\
(0.000740)\end{array}$ & $\begin{array}{c}0.000776 \\
(0.000576)\end{array}$ & $\begin{array}{l}-0.000399 \\
(0.000951)\end{array}$ & $\begin{array}{l}-2.75 \times 10^{-5} \\
(0.000672)\end{array}$ & $\begin{array}{c}0.000801 \\
(0.000545)\end{array}$ & $\begin{array}{c}8.80 \times 10^{-5} \\
(0.000849)\end{array}$ & $\begin{array}{c}0.001789 \\
(0.001296)\end{array}$ \\
\hline
\end{tabular}
equation and in the conditional variance equation)

Notes: (1) Values of standard errors in the brackets. (2) The number of the equation in the first column indicates whether the estimated parameters relate to the variables in the mean equation or in the conditional variance equation of the GARCH model. (3) Cells in grey indicate statistically significant estimates.

$*, * *, * *$ - denotes the significance at the $0.1,0.05,0.01$ level, respectively.

Source: authors' own calculations. 
Table A3b

Estimates of dummy variables for the NBP announcement days with announcement dummies in the conditional variance equation (22):

$$
h_{t}=\beta_{0}+\beta_{1} \xi_{t-1}^{2}+\beta_{2} h_{t-1}+\beta_{3} D U M_{t}
$$

from the GARCH model (21)-(22) of the PLN/USD exchange rate bid-ask spread percentage changes and in the mean equation (23):

$$
\text { rspread }_{t}=\alpha_{0}+\alpha_{1} r_{t-1}^{P L N / U S D}+\alpha_{2} D U M_{t}+\xi_{t}
$$

from the GARCH model (23)-(24) of the PLN/USD exchange rate bid-ask spread percentage changes (results from separate estimations

\begin{tabular}{|c|c|c|c|c|c|c|c|c|c|}
\hline Equation: & INTRATE & $M S$ & $R M$ & $\boldsymbol{B P M}$ & $B P Q$ & OFRES & $A L$ & FDEBT & IIP \\
\hline & \multicolumn{9}{|c|}{ On day $t$} \\
\hline \multirow[t]{2}{*}{ (22) } & $\begin{array}{c}-0.018912 * * * \\
\quad(0.005302)\end{array}$ & $\begin{array}{c}-0.008218 * * \\
(0.003432)\end{array}$ & $\begin{array}{c}-0.008303 * * * \\
(0.002992)\end{array}$ & $\begin{array}{c}-0.008991 * \\
(0.005249)\end{array}$ & $\begin{array}{c}-0.020446 * * \\
(0.008212)\end{array}$ & $\begin{array}{c}-0.012323 * * \\
(0.005447)\end{array}$ & $\begin{array}{c}-0.011158 * \\
(0.006122)\end{array}$ & $\begin{array}{c}-0.014024 * \\
(0.008241)\end{array}$ & $\begin{array}{c}-0.015692 * * \\
(0.007302)\end{array}$ \\
\hline & \multicolumn{9}{|c|}{ On day $t+1$} \\
\hline \multirow[t]{2}{*}{ (22) } & $\begin{array}{c}-0.018077 * * * \\
(0.005727)\end{array}$ & $\begin{array}{c}-0.005558 \\
(0.009870)\end{array}$ & $\begin{array}{c}-0.013782 * * * \\
(0.004311)\end{array}$ & $\begin{array}{l}-0.004275 \\
(0.010498)\end{array}$ & $\begin{array}{c}-0.014225 * \\
(0.007938)\end{array}$ & $\begin{array}{c}-0.010674 * * \\
(0.004952)\end{array}$ & $\begin{array}{l}-0.004335 \\
(0.005547)\end{array}$ & $\begin{array}{l}-0.008513 \\
(0.008555)\end{array}$ & $\begin{array}{c}-0.004822 * \\
(0.002643)\end{array}$ \\
\hline & \multicolumn{9}{|c|}{ On day $t$} \\
\hline \multirow[t]{2}{*}{ (23) } & $\begin{array}{r}-0.003719 \\
(0.021314)\end{array}$ & $\begin{array}{c}0.025288 * \\
(0.013910)\end{array}$ & $\begin{array}{c}0.009330 \\
(0.021379)\end{array}$ & $\begin{array}{r}-0.012629 \\
(0.017842)\end{array}$ & $\begin{array}{l}0.051613 * * \\
(0.020897)\end{array}$ & $\begin{array}{c}0.003395 \\
(0.022877)\end{array}$ & $\begin{array}{l}-0.011502 \\
(0.015370)\end{array}$ & $\begin{array}{c}-0.046803 * * \\
(0.021736)\end{array}$ & $\begin{array}{c}-0.063841 * * \\
(0.030883)\end{array}$ \\
\hline & \multicolumn{9}{|c|}{ On day $t+1$} \\
\hline (23) & $\begin{array}{l}-0.000547 \\
(0.023201)\end{array}$ & $\begin{array}{l}-0.011851 \\
(0.017844)\end{array}$ & $\begin{array}{c}0.010656 \\
(0.018714)\end{array}$ & $\begin{array}{l}-0.014386 \\
(0.017643)\end{array}$ & $\begin{array}{l}-0.007381 \\
(0.031786)\end{array}$ & $\begin{array}{c}0.008838 \\
(0.018730)\end{array}$ & $\begin{array}{l}-0.009890 \\
(0.019092)\end{array}$ & $\begin{array}{c}0.006928 \\
(0.030255)\end{array}$ & $\begin{array}{c}-0.007312 \\
(0.040017)\end{array}$ \\
\hline
\end{tabular}
of parameters in the mean equation and in the conditional variance equation)

Notes: (1) Values of standard errors in the brackets. (2) The number of the equation in the first column indicates whether the estimated parameters relate to the variables in the mean equation or in the conditional variance equation of the GARCH model. (3) Cells in grey indicate statistically significant estimates.

$*, * *, * * *$ denotes the significance at the $0.1,0.05,0.01$ level, respectively.

Source: authors' own calculations. 